\title{
STRONG IMPACTS OF GRAZING AMPHIPODS ON THE ORGANIZATION OF A BENTHIC COMMUNITY
}

\author{
J. EMmett DufFy ${ }^{1,3}$ AND Mark E. HAY ${ }^{2}$ \\ ${ }^{1}$ School of Marine Science and Virginia Institute of Marine Science, The College of William and Mary, \\ Gloucester Point, Virginia 23062-1346 USA \\ ${ }^{2}$ School of Biology, Georgia Institute of Technology, Atlanta, Georgia 30332-0230 USA
}

\begin{abstract}
Large brown seaweeds dominate coastal hard substrata throughout many of the world's oceans. In coastal North Carolina, USA, this dominance by brown seaweeds is facilitated by omnivorous fishes, which feed both on red and green algae and on herbivorous amphipods that graze brown algae. When fish are removed in the field, brown seaweeds are replaced by red seaweeds, and herbivorous amphipods are more abundant. Using an array of large $(\sim 4000 \mathrm{~L})$ outdoor mesocosms, we tested three mechanistic hypotheses for this pattern: fish feeding facilitates brown algal dominance (1) by removing red and green algal competitors, (2) by removing amphipods and reducing their feeding on brown seaweeds, or (3) through an interaction of these mechanisms. Our experiments revealed strong impacts of both fish and amphipods, and a key role for the interaction, in structuring this community. When both fish and amphipods were removed (the latter with dilute insecticide), space was rapidly dominated and held for 17 weeks by fast-growing, primarily filamentous green algae. In contrast, when either fish, amphipods, or both were present, green algae were cropped to a sparse turf, and space was more rapidly dominated by larger macroalgae. The impacts of amphipods and fish on late-successional macroalgal assemblages were comparable in magnitude, but different in sign: red seaweeds prevailed in the amphipoddominated treatment, whereas browns dominated in the presence of fish. Laboratory feeding assays and amphipod densities in the tanks suggested that the significant effects of amphipods were attributable largely, if not exclusively, to the single amphipod species Ampithoe longimana, which fed heavily on brown macroalgae. Our experimental removal of red and green algae failed to enhance cover of brown algae significantly; however, the latter reached substantially lower cover in the grazer-removal treatment, where green algae were very abundant, than in the fish-only treatment, where green algae were sparse. Thus, our results support the third hypothesis: fish-mediated dominance of brown algae involves both suppression of grazing amphipods and removal of algal competitors. Although collective impacts of fish and amphipods on this benthic community were generally comparable in magnitude, impacts normalized to each grazer's aggregate biomass were consistently higher for amphipods than for fish, sometimes by 1-2 orders of magnitude. Thus, the impacts of grazing amphipods (specifically A. longimana) on the benthic community were both strong and disproportionate to their biomass. These experimental results imply that grazing amphipods, which are ubiquitous in marine vegetation but poorly understood ecologically, may play important roles in the organization of benthic communities, particularly where predation pressure is low.
\end{abstract}

Key words: amphipods; Ampithoe longimana; community organization; Diplodus holbrooki; food webs; mesocosms; North Carolina, USA; seaweeds; trophic cascade.

\section{INTRODUCTION}

A long and distinguished tradition of experimental field studies demonstrates that marine herbivores, particularly mollusks and sea urchins in rocky shore habitats (Paine and Vadas 1969, Dayton 1975, Lubchenco 1978, Lubchenco and Menge 1978, Paine 1992), and fishes and urchins on tropical reefs (Randall 1961, Ogden et al. 1973, Carpenter 1986, Lewis 1986, Lessios 1988, Morrison 1988, Hay 1991) play key roles in the organization and functioning of marine benthic com-

Manuscript received 17 August 1998; revised 12 March 1999; accepted 14 May 1999.

3 E-mail: jeduffy@vims.edu munities. Such studies have been seminal in establishing field experiments as a standard approach in community ecology (Paine 1980, Hairston 1989) and have made major contributions to our understanding of food webs and trophic transfer in marine systems. These studies also have been pivotal in establishing the general principles of community organization that transcend habitat boundaries. Through these types of investigations, benthic marine ecologists have gained an understanding of the dynamics of community structure that may be as complete and as subtle as is currently available for any community (Dayton 1971, 1975, Connell 1972, Lubchenco and Menge 1978, Paine 1980, 1992, Menge and Lubchenco 1981, John et al. 1992, 
Hughes 1994, Estes and Duggins 1995, Menge 1995, Hay 1997).

Given this history, it is noteworthy that we remain largely ignorant of the trophic and ecological roles played by the small, mobile herbivores (mesograzers) that abound in the nearshore benthos. Marine algae and seagrasses harbor diverse assemblages of small, mobile invertebrates dominated by peracarid crustaceans, gastropod mollusks, and polychaete worms (Colman 1940, Wieser 1952, Nagle 1968, Mukai 1971, Choat and Kingett 1982, Edgar 1983a, b, $c, d$, Dean and Connell 1987). These mesograzers are ubiquitous in nearly all vegetated habitats and can occur in tremendous densities. In systems such as shallow reef crests (Brawley and Adey 1981) and seagrass beds (Jernakoff et al. 1996) where grazing fishes and macroinvertebrates such as sea urchins are usually not abundant, mesograzers appear to be the dominant primary consumers (Orth and van Montfrans 1984, Brawley 1992). Because of their small size, high abundance, short generation times, and consequently high rates of secondary production (Fredette and Diaz 1986, Fredette et al. 1990, Edgar 1993), mesograzers, and particularly the crustaceans, are major conduits of primary production to higher trophic levels (Kikuchi 1974, Adams 1976b, Kitting et al. 1984, Edgar and Shaw 1995), and are thus critical players in near-shore trophic transfer.

Although their role in trophic transfer is widely acknowledged, the potential impacts of mesograzers on the structure of natural communities are virtually unknown compared with the well-documented impacts of macrograzers. This is due in large part to the formidable logistical challenges to manipulating mesograzer densities under realistic conditions. Yet the same characteristics that make mesograzers important trophic links in food chains-abundance, rapid population growth and production-suggest that they could have important impacts on plant assemblages belied by their low standing biomass and general inconspicuousness. Mesograzers as a group are also both taxonomically and ecologically diverse. In many marine communities, the number of mobile epifaunal invertebrate species (not including meiofauna) inhabiting algae or seagrasses runs in the 10 s to 100 s (Nelson 1979a, Stoner 1980b, Edgar 1983a, 1990, Dean and Connell 1987), sometimes exceeding the number of macrograzer species by an order of magnitude or more. Although many of these epifaunal species appear to feed on microbiota and detritus, a significant but poorly known fraction of them feed on algae ranging from microalgae to giant kelps (van Montfrans et al. 1984, Duffy 1990, Duffy and Hay 1991a, Brawley 1992, Cronin and Hay 1996, Jernakoff et al. 1996, Poore and Steinberg 1999, Cruz-Rivera and Hay 2000).

A limited number of observational and experimental studies suggests that mesograzer feeding can influence the composition of benthic plant assemblages. One of the first of these was Brawley and Adey's (1981) dem- onstration that, in a coral-reef mesocosm, filamentous algal turfs gave way to dominance by red macroalgae after introduction of the grazing amphipod Ampithoe raimondi. Subsequent experiments (Kennelly 1983, 1991, Zeller 1988) and observations (Kangas et al. 1982, Haahtela 1984, Tegner and Dayton 1987) also demonstrated changes in marine algal assemblages concomitant with population increases of epifaunal invertebrates. The most explicit attention to the potential importance of mesograzers, however, has been in seagrass beds, where these animals often comprise the dominant primary consumers (Kitting et al. 1984, Orth and van Montfrans 1984, van Montfrans et al. 1984, Jernakoff et al. 1996). In these systems, competition from fast-growing epiphytes is a frequent threat to the seagrasses, such that the growth and general vigor of seagrass beds is likely to depend on suppression of these epiphytes. Numerous studies have addressed this general hypothesis by focusing on the potential impacts of grazing crustaceans and gastropods on epiphyte accumulation on seagrasses (reviewed in Jernakoff et al. [1996]). But the results have been equivocal. On the one hand, it is clear that many mesograzers feed on epiphytic algae in preference to seagrasses, and much evidence suggests that this feeding is beneficial for the grasses. But with few exceptions (e.g., Neckles et al. 1993), such studies have been largely observational, of short duration, unreplicated, or frustrated by other design problems. Thus the mounting evidence for the importance of mesograzers in marine communities is mostly circumstantial, or was obtained under artificial conditions at small spatial and temporal scales. What is lacking is an adequately replicated, experimental study in something approaching a natural benthic community over an entire growing season.

Here we present results of a study designed to assess experimentally the relative importance of grazing by omnivorous fishes, grazing by amphipods, and competition among algae, in mediating the characteristic pattern of brown algal dominance on hard substrata in North Carolina, USA. Using a replicated array of large $(\sim 4000$ L), outdoor mesocosm tanks supplied with flowing, unfiltered seawater, we manipulated the abundance of omnivorous fish and grazing amphipods in a factorial experiment, and followed benthic succession for five months. We addressed the following questions: (1) Do fish promote dominance of brown seaweeds by removing their competitors, by removing their (meso)grazers, or both? (2) Do mesograzers have measurable impacts on benthic community organization, and if so how do they compare, qualitatively, with those of fishes? (3) Which mesograzer species have the greatest impact on community organization?

\section{Methods}

Natural history of the system

Our study focused on the seaweed-dominated community that occurs on hard substrata in coastal North 
TABLE 1. Field abundances of key organisms studied in the mesocosm experiments.

\begin{tabular}{|c|c|c|c|c|}
\hline Organism & Abundance & Units & Season & Reference \\
\hline Brown algae & $\sim 20$ & $\%$ cover & Oct & Miller and Hay (1996) \\
\hline Sargassum filipendula & 585 & $\mathrm{~g}$ wet $\mathrm{mass} / \mathrm{m}^{2}$ & Jul & Hay (1986) \\
\hline Dictyota spp. & 44 & $\mathrm{~g}$ wet $\mathrm{mass} / \mathrm{m}^{2}$ & Jul & Hay (1986) \\
\hline Padina gymnospora & 39 & $\mathrm{~g}$ wet $\mathrm{mass} / \mathrm{m}^{2}$ & Jul & Hay (1986) \\
\hline Red algae & $\sim 3$ & $\%$ cover & Oct & Miller and Hay (1996) \\
\hline Hypnea musciformis & 9 & $\mathrm{~g}$ wet $\mathrm{mass} / \mathrm{m}^{2}$ & Jul & Hay (1986) \\
\hline Chondria dasyphylla & 0.5 & $\mathrm{~g}$ wet $\mathrm{mass} / \mathrm{m}^{2}$ & Jul & Hay (1986) \\
\hline \multicolumn{5}{|l|}{ Green algae } \\
\hline Enteromorpha spp. & 0.4 & g wet $\mathrm{mass} / \mathrm{m}^{2}$ & Jul & Hay (1986) \\
\hline Ulva spp. & 0.07 & $\mathrm{~g}$ wet $\mathrm{mass} / \mathrm{m}^{2}$ & Jul & Hay (1986) \\
\hline \multicolumn{5}{|l|}{ Grazers } \\
\hline Spottail pinfish (Diplodus holbrooki) & $7-8$ & no. $/ \mathrm{m}^{2}$ & Jul & Hay (1986) \\
\hline Total amphipods & to 130 & no./g wet algae & Jun & Duffy $(1990)$ \\
\hline Ampithoe longimana & $0-4$ & no./g wet algae & Jun-Aug & Duffy and Hay $(1991 b, 1994)$ \\
\hline
\end{tabular}

Notes: All data are from Radio Island Jetty, North Carolina, USA, except those for Ampithoe longimana from Radio Island Jetty and Lennoxville Point, North Carolina. Values reported are means, except for total amphipods and Ampithoe longimana (range).

Carolina during warmer months of the year (Table 1). Previous studies in this, and adjoining, systems (Adams 1976a, Hay 1986, Hay and Sutherland 1988, Duffy 1990, Duffy and Hay 1991b, 1994) have revealed a characteristic seasonal pattern of plant and animal succession as follows. As water temperatures warm in spring, fish densities in nearshore habitats increase rapidly due to recruitment of young-of-year and immigration of adults from deeper wintering areas. Over hard substrata, much of the nearshore fish biomass is made up of omnivorous spottail pinfish Diplodus holbrooki (M. E. Hay, unpublished data). Juvenile D. holbrooki, like many other common coastal species, begin feeding on planktonic copepods and epifaunal crustaceans as they settle out of the plankton; as they grow to adult size, their diet expands to include an increasing proportion of benthic algae, which comprises the major fraction of the diet by late summer (Darcy 1985b; M. E. Hay, unpublished data). D. holbrooki appears to have similar habits to the other common sparid in our area, Logodon rhomboides, which despite its primarily herbivorous adult diet, feeds actively on small crustaceans in preference to algae when these animals are available (Holmlund et al. 1990). In late fall as water temperatures drop, $D$. holbrooki migrates offshore.

During the winter and early spring, seaweed assemblages on hard substrata support very high densities of mobile epifauna, dominated by the suspension-feeding amphipods Caprella penantis and Jassa marmorata (formerly J. falcata; Duffy [1990]). The arrival of large numbers of juvenile fishes in spring is generally accompanied by a marked decline in epifaunal abundance, and a shift in species relative abundance and size frequency distribution (Nelson 1979b, Duffy 1990, Duffy and Hay 1991b, 1994). During the late summer period of high fish abundance, these epifaunal assemblages remain at relatively low densities (Duffy and Hay 1991b); the major macrophyte-grazing mesoher- bivores are Ampithoe longimana in the summer and $A$. marcuzii during colder months (Hay et al. 1987, Duffy 1990, Duffy and Hay 1991b, 1994).

The seaweed assemblage also shows predictable seasonal changes (Schneider and Searles 1991; M.E. Hay, unpublished data). In spring, several red and green algae flourish, gradually giving way during summer to an assemblage dominated by brown seaweeds (primarily Sargassum filipendula, Dictyota menstrualis, D. ciliolata, and Padina gymnospora) that are unpalatable to grazing fishes. These seaweeds persist through fall. Experimental exclusion of fishes in the field prevents this transition to brown dominance, with red macroalgae, which are palatable to local grazing fishes, dominating the substratum in fish exclusion cages (Miller and Hay 1996). In late fall as water temperatures drop, the brown seaweeds listed above, most of which are of tropical/warm temperate distribution, begin to senesce. The winter flora is dominated by senescent $S$. filipendula, and filamentous and bladed algae of more northerly distribution.

Spottail pinfish differ markedly from the common grazing amphipods in their feeding preferences among the local algal species. Both spottails and the other common omnivorous sparid in our area, Lagodon rhomboides, feed preferentially on green and red algae and avoid browns (Hay 1986, Hay et al. 1987, 1988). The local ampithoid amphipods, in contrast, generally feed more heavily on browns than on other macroalgae (Hay et al. 1987, Duffy 1990, Duffy and Hay 1991b, 1994).

\section{Experimental design}

The primary focus of our study was a mesocosm experiment manipulating the densities of Diplodus holbrooki, grazing amphipods, and red and green algae, in a replicated factorial design. We followed the succession of benthic communities on concrete blocks in 

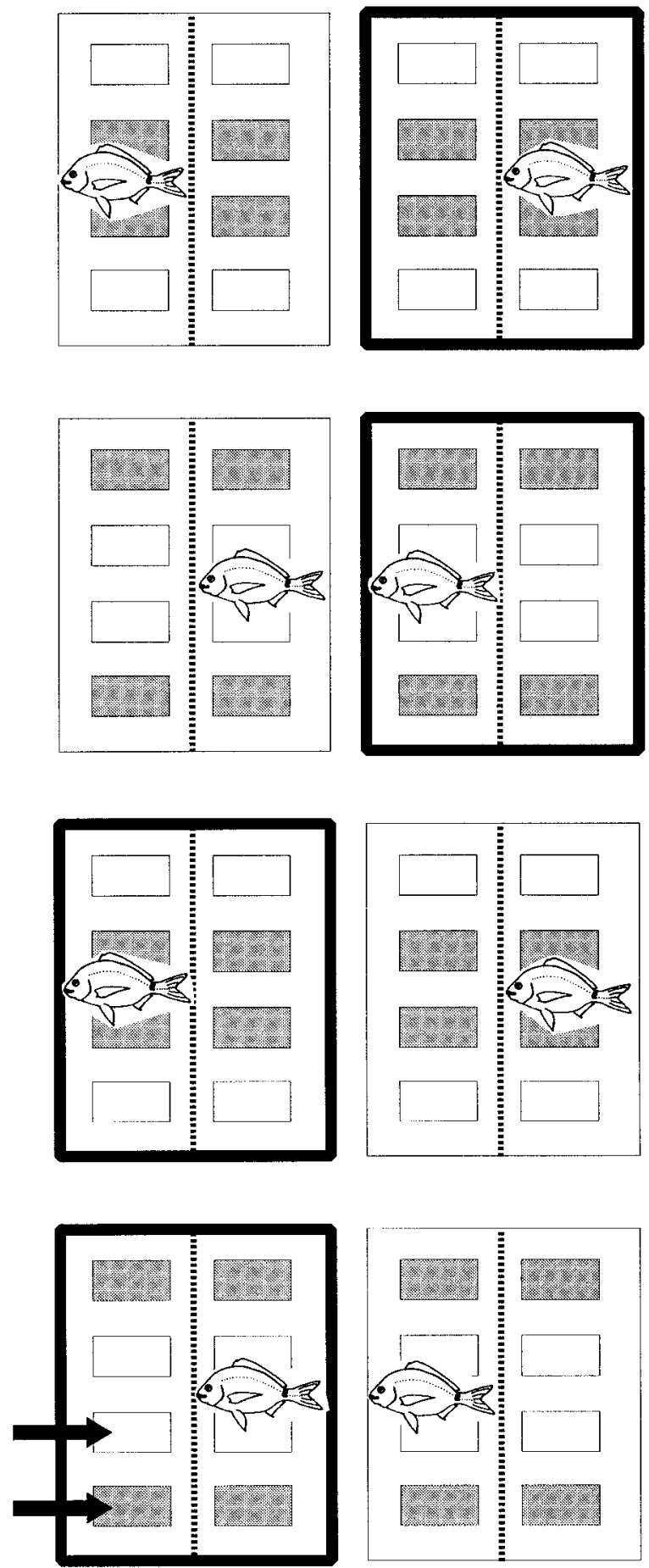

FIG. 1. Schematic illustration of the mesocosm experiment's design. Each large rectangle represents a tank, subdivided longitudinally by a mesh panel (dotted line) into fish-inclusion and fish-exclusion compartments (only the forward half of each tank is shown; the back half was not used). Tanks in heavy outline were treated with insecticide; those in light outline were not. The four smaller rectangles within each compartment represent the individual concrete block substrata, two of which had red and green algae removed weekly (competitor removal) and two of which were left undisturbed (control). Arrows show no removal (open rectangle) and competitor removal (shaded rectangle). each treatment over the course of 22 weeks. We conducted the experiment in a series of eight $\sim 4000-\mathrm{L}$ stainless steel tanks located behind the University of North Carolina at Chapel Hill's Institute of Marine Science in Morehead City, North Carolina, USA. The tanks are outdoors and are supplied with a constant flow of raw, unfiltered seawater from adjacent Bogue Sound. Each tank is supplied with a $\sim 60$-L dump-bucket that generates waves. Seawater is pumped into this bucket until it fills, becomes unstable, and then dumps into the tank, creating a wave that travels the length of the tank, maintaining turbulent water circulation throughout and simulating the natural physical environment on local rock jetties. The water then drains from a standpipe at the downstream end. The tanks are exposed to ambient conditions of light, temperature, and weather.

In our experiment, each tank was divided into four compartments using $1.9-\mathrm{cm}$ plastic mesh. We used only the two upstream compartments in each tank because we were concerned that the compartments that were remote from the wave generator might not be exposed to adequate turbulence. After inoculating the mesocosms with seaweeds and mesograzers (see next section), four concrete cinder blocks were placed on the bottom of each compartment. We monitored the benthic communities that developed on the top surfaces of these blocks.

The experiment was designed to test the relative importance of (1) fish grazing, (2) mesoherbivore (specifically amphipod) grazing, and (3) competition among algae in mediating the dominance by brown macroalgae observed on local hard substrata in the field, and in previous mesocosm experiments (see Hay 1986, Miller and Hay 1996). We used a modified factorial design to separate the effects of these three factors (Fig. 1). First, to assess the effects of mesograzers, we treated four of the eight tanks with a dilute solution of insecticide (liquid Sevin [Ortho, Marysville, Ohio, USA], active ingredient 1-napthyl n-methylcarbamate, see Methods: Evaluation of insecticide effects below) to maintain reduced densities of small, mobile invertebrates. The remaining four tanks were untreated and served as controls. Insecticide tanks were treated on days $1,11,63$, and 152 of the experiment by shutting off water flow, adding $3.7 \mathrm{~mL}$ of full-strength liquid Sevin solution ( $=1.0 \mathrm{~g}$ active ingredient) to a bucket of seawater, dumping this solution into the tank, stirring the tank briefly with a stick to attain a concentration of $\sim 1 \mu \mathrm{L} / \mathrm{L}$, and allowing the Sevin to work for $\sim 30$ min before restoring water flow to the tanks. Water flow was stopped and restored in the control tanks for the same period. Second, to assess the effects of fish, we stocked fish in one of the two compartments in each tank. Finally, to assess the importance of competition from red and green algae in suppressing brown algal dominance, we manually removed red and green algae from two of the four blocks in each compartment, leav- 
ing the remaining two blocks undisturbed as controls. Reds and greens were removed weekly through the end of September, and less frequently thereafter, when algal growth rates appeared lower. Data from the two blocks of the same treatment (competitor removals or controls) within a compartment were pooled, and treated as a single datum, in all analyses. There were thus four grazing treatments which, because insecticide primarily affected amphipods, we refer to as: (1) "grazerremoval" (-amphipods/-fish), (2) "fish-dominated" (-amphipods/+fish), (3) "amphipod-dominated" (+amphipods/-fish), and (4) "fish + amphipods" (+amphipods/+fish). Each grazer treatment contained a nested pair of competition treatments (removal and control, Fig. 1), yielding a total of eight treatments. Each of the eight treatments was replicated four times.

\section{Stocking the mesocosm tanks}

The experiment was initiated on 3 June 1991, when we placed the concrete substratum blocks into the clean tanks and began pumping seawater into them. After three to four weeks, we stocked the tanks with eight species of seaweeds in wet masses approximating those measured in an equivalent area at the same time of year at nearby Radio Island Jetty. The species were the red algae Hypnea musciformis ( $\sim 11 \mathrm{~g})$, Gracilaria tikvahiae ( $\sim 12 \mathrm{~g})$, and Chondria dasyphylla ( $\sim 12 \mathrm{~g})$; the brown algae Sargassum filipendula $(\sim 10 \mathrm{~g})$, Padina gymnospora $(\sim 5 \mathrm{~g})$, and Dictyota menstrualis $(\sim 10 \mathrm{~g})$; and the green algae Codium fragile $(\sim 20 \mathrm{~g})$, and Ulva spp. ( $\sim 7 \mathrm{~g})$. A handful each of the red seaweeds $\mathrm{Ca}$ lonitophyllum medium and Rhodymenia pseudopalmata, which are found in low abundances at Radio Island, were also added to each compartment. These plants, which were not defaunated, provided an initial inoculum of mesograzers and epiphytic algae, foods for our consumers, and a local spore source for further colonization of mesocosm surfaces. The algae were attached to the mesh sides of the compartment with cable ties. On 8 July, we added eight spottail pinfish (Diplodus holbrooki) to each of the fish-inclusion compartments. This fish density (6.8 individuals $/ \mathrm{m}^{2}$ of foraging area) is similar to the mean recorded during summer in the field (Table 1, Hay 1986).

\section{Statistical analysis of the mesocosm experiments}

The design of the mesocosm experiment is complex, involving three factors (insecticide, fish, competition), nine measurement dates, and a large number of potential response variables. One treatment (insecticide) was coincident with the blocking factor (tank), and the other two were nested within levels of the insecticide treatment (competition within fish within insecticide). Analysis of the experiment thus posed some challenges, which we have chosen to approach as follows. First, to simplify interpretation and reduce the total number of statistical tests, we aggregated algal species into higher taxa, namely green, red, and brown macroalgae, and our analysis concentrates on how treatments affected these groups. This approach is justified by previous studies showing that grazer feeding rates in this system are generally much more similar for common species within these algal groups than among them (Hay et al. 1987, 1988, Duffy and Hay 1991b). Second, we reduced the total number of dates analyzed by testing for treatment effects on a given algal taxon only on the date at which that taxon reached its highest overall abundance. We opted for this approach rather than using repeated-measures ANOVA because the latter often produces a large number of significant interaction terms, which require post hoc lower-level ANOVAs to dissect out interpretable effects. Instead we planned comparisons in advance based on ecologically relevant criteria (i.e., major algal groups on dates of peak occurrence).

To compare the impacts of different grazer treatments, our analysis held competition constant (i.e., by considering only the non removal blocks in each compartment). These tests involved four grazer treatments (see Methods: Experimental design). Because mesograzer reductions could only be achieved by treating entire tanks with insecticide, our design was not a completely randomized factorial one; instead, fish and no-fish treatments are paired within tanks, whereas insecticide and no-insecticide tanks are unpaired and, moreover, coincide with the blocking factor for the fish treatment. This constitutes a split-plot design, and we analyzed the results using the split-plot ANOVA developed for such designs (Potvin 1993). There were four independent replicates for each treatment combination. A limitation of this design and analysis is the inability to separate the variance due to block (in this case, tank) effect from that due to one of the treatments (in this case, mesograzer removal).

To assess the importance of competition among algae, we compared the cover of brown algae on blocks from which red and green algae were removed vs. on undisturbed blocks. Because each experimental unit (tank compartment) of a grazer treatment contained both competitor-removal and control blocks, we compared the difference in brown cover between the paired control and removal blocks within each compartment using paired-sample $t$ tests. Separate tests were run for each combination of date and grazer treatment, but we used the sequential Bonferroni procedure (Rice 1989) to maintain overall $\alpha$ at 0.05 for the set of tests.

Before conducting any statistical analyses, we evaluated heterogeneity of variances among treatments using Cochran's test. In all cases where significant heterogeneity was found, variance was approximately proportional to the mean, so we transformed the data by $\log (x+1)$ and reran Cochran's test. In most cases this homogenized the variances and we proceeded with ANOVA. In a few cases transformation reduced but failed to eliminate variance heterogeneity so we ran the ANOVA on the transformed data with reduced variance 
heterogeneity. All statistical analyses were performed using SAS version 6.12 (SAS 1985).

\section{Evaluation of insecticide effects}

We used the insecticide Sevin (1-napthyl n-methylcarbamate) to suppress amphipods in our experiment. This product is a cholinesterase inhibitor in insects (Casida 1963, Matsumura 1985) and appears to have a similar mode of action against several marine arthropods (Buchanan et al. 1985). Our experiment relies on the assumption that treatment with Sevin depresses abundances of mesograzers (specifically amphipods) but has negligible effects on other organisms. This assumption is supported by several lines of evidence: (1) Sevin is very effective against many marine crustaceans, but has little effect on mollusks or fishes; to affect the latter animals significantly, Sevin must be applied at concentrations 10 to 300 times greater than those that kill crustaceans (Buchanan et al. 1985). (2) Sevin has been extensively used for nearly 40 years in estuaries of the northeastern Pacific to rid commercial oyster beds of burrowing shrimps and crabs. Although it is applied at high concentrations from helicopters, no detrimental, long-term effects on fishes have been detected (Buchanan et al. 1985; D. A. Armstrong, personal communication). (3) Carpenter (1986) successfully used Sevin to conduct mesograzer removals on a coral reef and demonstrated that it had no detectable effects on algal biomass or productivity over the 4month period of his study. Although the concentration of Sevin and frequency of application that we used in our experiments were less than those used or evaluated in the above studies, we nevertheless evaluated its potential effects on target and nontarget animals in our system.

Amphipods.-To determine the susceptibility of mesograzers to insecticide, we exposed groups of five individuals of the amphipod Ampithoe longimana $(n=$ 6 groups) to insecticide at a concentration of $1 \mu \mathrm{L} / \mathrm{L}$ in bowls of seawater, and recorded the time elapsed until all five amphipods in a replicate bowl had died. Another six groups of five individuals each were observed in bowls of untreated seawater as controls. We compared the proportion of individuals surviving in Sevin and control treatments after one hour using a Mann-Whitney $U$ test.

Fish.-We assessed the impacts of insecticide at 1 $\mu \mathrm{L} / \mathrm{L}$ on both survival and growth of spottail pinfish over $39 \mathrm{~d}$ in the laboratory, using the following design. Thirty fish were collected from the field and acclimated for 7-10 $\mathrm{d}$ in the laboratory flowing-seawater system until they were feeding regularly on commercial pellet food. They were then measured for standard length, and a single fish was placed in each of 3038 -L aquaria supplied with flowing seawater. Fifteen of the tanks were assigned as control tanks, and the other 15 tanks were assigned as insecticide-treatment tanks. To control for differences in feeding rate among individuals, a control fish was paired with a treatment fish of approximately the same size in an adjacent tank, and the two were fed equal amounts of food. We accomplished this by alternately offering each fish a single pellet of commercial fish food until one of them stopped eating, at which point neither of the fish was offered more food. This ensured that both fish in a pair received the same ration. Fish were fed once each day, and the number of pellets eaten by each was recorded at each feeding. On three occasions (days 13, 20, and 27) during the 39-d experiment, the water supply to each tank was shut off and a solution of insecticide was added to the treatment tank of each pair and mixed through the water to achieve a concentration of $1 \mu \mathrm{L} / \mathrm{L}$. After $1 \mathrm{~h}$ the water flow was resumed to all tanks. At the end of the experiment, the standard length of each fish was remeasured.

\section{Monitoring benthic succession and mesograzer abundance}

We monitored benthic succession by measuring percent cover of benthic organisms on the concrete substrata, allowing repeated nondestructive sampling of the community. Percent cover of benthic organisms was measured on nine dates by identifying taxa under each of 100 points within a quadrat lain over the surface of each block. In cases where more than one species overlapped under a given point, each was counted as one; thus total cover could exceed $100 \%$.

Standing biomass of benthic taxa was measured at the end of the experiment, when all organisms were scraped from the blocks and preserved. Samples from this final harvest were sorted by taxon, generally to species for algae and more conspicuous sessile animals, and to higher taxa for smaller and rarer organisms. They were then dried to constant mass at $60^{\circ} \mathrm{C}$, weighed, ashed in a muffle furnace at $450^{\circ} \mathrm{C}$, and reweighed.

We estimated mesograzer abundance in the tanks in September by counting and identifying the animals colonizing brown seaweeds deployed in the tanks during a grazing assay (see Methods: Grazer impacts below). At the end of the assay, we gently removed the deployed algal pieces from the tanks, taking care to avoid disturbing associated animals. We then removed associated animals from the algae by decanting the water from the holding bag through a 500- $\mu \mathrm{m}$ mesh sieve, and rinsing the alga repeatedly in tap water to dislodge animals; all rinse water was passed through the sieve, and the collected animals were preserved in $10 \%$ formalin. Animals were counted and identified from one thallus of each algal species deployed in each section of each tank.

\section{Grazer impacts on brown seaweeds}

We used two sources of evidence to test the impacts of mesograzers on brown algae in the mesocosm experiment. First, to measure mesograzer impact on the 
dominant browns directly, we deployed pieces of Sargassum filipendula, Dictyota menstrualis, and Padina gymnospora in the tanks in two separate experiments, one in August and one in September. In August, one piece of each of the three algal species (initial blotted wet mass $=4.36-5.97 \mathrm{~g}$ ) was attached to the mesh side of the compartment with a cable tie. The algal pieces were left for $7 \mathrm{~d}$, after which the remaining portion of each was gently enclosed in a separate plastic bag, removed from the mesh wall, and the bag was sealed. In the laboratory, the plant portion was blotted dry and weighed again to obtain the change in mass during the 7-d experiment. The September experiment was similar except that three pieces of each species were deployed in each tank; after the remaining algal portions had been retrieved at the end of $8 \mathrm{~d}$, the mean mass change of the three portions of a given species in a compartment was used as the datum for analysis.

As a second estimate of mesograzer damage, at the conclusion of the experiment we measured the size (area) of fronds remaining on plants of Sargassum filipendula that had settled and grown on blocks in the tanks. This alga was the dominant brown seaweed in the tanks. After plants were harvested, we photocopied five fronds selected randomly from each of five plants from each substratum block; we then measured the areas of all fronds from one block in each tank compartment using the digitizing program NIH image (National Institutes of Health, Bethesda, Maryland, USA). This technique estimates only the total area and perimeter of the frond, rather than the amount lost to grazing. Since grazing appeared to be the primary process producing differences in frond area among treatments, we considered this a reasonable approach to estimating, albeit crudely, the impact of grazing at the level of individual fronds.

\section{Laboratory feeding assays}

To evaluate which of the common mesograzer species contributed most to treatment effects on macroalgae observed in the tank experiment, we measured feeding rates of each of six epifaunal species on seven species of algae in the laboratory. No-choice assays were conducted for six of the most abundant epifaunal species that were known or suspected of being herbivorous, namely the amphipods Ampithoe longimana, Dulichiella appendiculata, and Elasmopus levis, the isopod Paracerceis caudata, and the gastropods Diastoma varium and Costoanachis sp. We measured their feeding rates on the green algae Cladophora ruchingeri and Enteromorpha sp., the red macroalgae Hypnea musciformis and Chondria dasyphylla, and the brown macroalgae Padina gymnospora, Dictyota menstrualis, and Sargassum filipendula. All assays were conducted simultaneously. Portions of algae were blotted dry (100-200 mg), weighed, and placed in replicate 100$\mathrm{mL}$ plastic cups with monospecific groups of grazers; an equal number of replicate cups received algal por- tions but no grazers (controls) and were used to calculate endogenous changes in algal mass unrelated to grazing. Grazer and control cups were paired by using algal portions from the same thallus. After 5-6 d, we removed the remaining algal portions from the cups, blotted, and reweighed them. The estimated amount grazed was calculated by comparing change in mass of the alga exposed to grazers with that of the paired control alga, after correcting for endogenous mass change in the grazer-exposed alga by subtracting the percentage change measured in the grazer-free control.

\section{Comparing impacts of fish and amphipods}

One of our primary interests in this experiment was to compare the relative importance of fish vs. mesograzers in impacting the algal assemblage, i.e., their relative interaction strengths. In addition to the traditional raw, arithmetic differences between treatments with and without the consumer, several other metrics have been proposed recently as more standardized estimates of interaction strength useful for comparison among different consumers, prey types, and environments (Berlow et al. 1999). Berlow et al. (1999) used simulation studies to compare the behavior of Paine's (1992) index (PI), the Index of Community Importance (CI, Power et al. 1996), the Dynamic Index (DI, Osenberg and Mittelbach 1995, Wootton 1997), and the raw difference under different conditions of prey and consumer density, type of consumer functional response, and proximity of the interaction to equilibrium. All of the indices were sensitive to one or more of these conditions, such that an appropriate index should be chosen carefully to reflect the specific question addressed and the conditions of the experiments used to calculate it.

Based on the results of Berlow et al. (1999), we chose to present our results on grazer effects in the form of raw (as opposed to proportional) differences among treatments. We calculated grazer effects separately for spottail pinfish and for grazing amphipods, using several response variables. These included the cover of green, red, and brown algae on the dates at which each reached its highest overall cover, as well as total benthic biomass and biomass of brown algae (the dominant benthic taxon) at the conclusion of the experiment. For each effect we calculated (1) the "collective" difference, i.e., the absolute difference between treatments resulting from the aggregate effects of all grazer individuals present, (2) the "per-biomass" difference, which is simply the collective effect of a grazer taxon divided by its aggregate biomass, and (3) the "percapita" difference, i.e., the collective effect divided by the number of individual grazers present. Of these three alternative measures of interaction strength, the percapita effect is perhaps most straightforward to interpret in that effects of grazers on plants are exerted by individual animals. Similarly, the per-capita effect is important in being the term most commonly used by 
TABLE 2. Estimation of grazer biomass in common units (g AFDM grazers/block).

\begin{tabular}{|c|c|c|c|c|c|}
\hline Term & Value & Value units & Source & Product & Product units \\
\hline \multicolumn{6}{|c|}{$\overline{\text { Grazing amphipods } \dagger}$} \\
\hline 1 & 17.3 & $\begin{array}{l}\text { no. grazing amphipods/g wet } \\
\text { algae }\end{array}$ & $\begin{array}{l}\text { Sargassum, Dictyota, Padina } \\
\text { (September) }\end{array}$ & $(17.3)$ & \\
\hline 2 & 9.26 & g wet algae/g AFDM algae & Sargassum & 160 & no. amphipods/g AFDM algae \\
\hline 3 & 0.002 & g AFDM/individual amphipod & Ampithoe longimana & 0.280 & $\begin{array}{l}\text { g AFDM amphipods/g AFDM } \\
\text { algae }\end{array}$ \\
\hline 4 & 1.07 & g AFDM algae/block & final harvest (December) & 0.300 & g AFDM amphipods/block \\
\hline \multicolumn{6}{|c|}{ Spottail pinfish } \\
\hline 1 & 83.7 & fish length $(\mathrm{mm})$ & final harvest (December) & (83.7) & \\
\hline 2 & 0.034 & $\begin{array}{l}\text { g AFDM Diplodus/length } \\
(\mathrm{mm})\end{array}$ & $\begin{array}{l}\text { measurements of field- } \\
\text { collected Diplodus }\end{array}$ & 2.81 & g AFDM/fish \\
\hline 3 & 7 & no. fish compartment & final harvest (December) & 19.7 & $\begin{array}{l}\text { g AFDM Diplodus/compart- } \\
\text { ment } \S\end{array}$ \\
\hline 4 & 0.064 & $\begin{array}{l}\text { block area as percentage of } \\
\text { total foraging area }\end{array}$ & $\begin{array}{l}\text { measurement (cage sides, } \\
\text { ends, blocks) }\end{array}$ & 1.26 & g AFDM Diplodus/block \\
\hline
\end{tabular}

theoreticians to model the dynamics of species interactions (Laska and Wootton 1998). Nonetheless, we consider the per-biomass effect a more useful alternative to the per-capita effect as a means of comparing grazer taxa, such as fish and amphipods, that differ greatly in body size (three orders of magnitude in the fish and amphipods we studied, Table 2) and abundance. Moreover, the per-biomass effect might be considered closer to an intrinsic measure of a species' impact in that population biomass is more tightly constrained by available energy or resources than is abundance. We used raw differences to calculate these effects for the following reasons. First, unlike PI and CI, the raw difference is symmetric about zero such that positive and negative effects of similar absolute value yield correspondingly similar values of the index. Second, DI performs poorly when prey abundances are near equilibrium. Since our estimates of grazer impact were measured on the date when the algal taxon reached highest abundance, they appear to be as close as this system gets to equilibrium, such that DI may be an inappropriate index.

Calculating the collective impact of grazers was straightforward, but estimation of grazer biomass required a series of conversions since grazer biomass was not measured directly. To compare biomass of fish and amphipods in common units, we estimated the aggregate ash-free dry mass (AFDM) of grazers per unit of bottom (i.e., block) area (Table 2). First, for fish, we measured the number and lengths of fish in each experimental compartment at the conclusion of the experiment, and estimated their AFDM using a subsequently measured length/AFDM relationship for $D$. holbrooki. Since the fish had access to the entire compartment, we then normalized fish AFDM to the area of a single concrete block as follows. The total area available for feeding within a compartment (surfaces of blocks plus area of plastic mesh compartment sides) was estimated, and the total AFDM of fish within the compartment was then multiplied by the fraction of that area comprised by a single block to obtain biomass of fish per block. To calculate biomass of amphipods (Table 2), we first converted amphipod abundance per gram wet algae in September (the only date on which such data were available) to abundance per gram AFDM algae, using a measured relationship for AFDM/wet mass of Sargassum filipendula. Next, grazing amphipod abundance was multiplied by mean AFDM per individual amphipod to obtain AFDM of amphipods per AFDM algae. Finally, we multiplied this number by the final benthic biomass harvested from a single block to normalize grazer biomass to the area of an individual concrete block.

A final issue in comparing effects of different grazers is the relevant "normal" treatment against which to compare the grazer-exclusion treatments. The estimated impact of a consumer on a prey assemblage can be influenced strongly by prey abundance and the presence of other grazers. In an attempt to dissect out the community impact of a single grazer taxon (e.g., amphipods) in isolation, as opposed to its impact in the intact community (e.g., containing both amphipods and fish), we calculated grazer effects using two complementary approaches. The "isolated" effect of a grazer is the difference between algal abundance in the presence of that grazer taxon alone vs. in the absence of all grazers. Thus, the isolated effect measures the grazer's total impacts on the target algal group, potentially including both direct effects (grazing) and indirect effects (e.g., mediation of competition among algae), in the absence of interaction with other grazers. The "net" effect of the grazer, in contrast, compares algal abundance in the intact (normal) assemblage with all grazer taxa present vs. that where the grazer in question has been deleted. 


\begin{tabular}{|cl|}
\hline$\nabla$ & GREEN ALGAE \\
- & RED ALGAE \\
$\wedge$ & BROWN ALGAE \\
$\square$ & BARE SPACE \\
\hline
\end{tabular}

GRAZER-REMOVAL

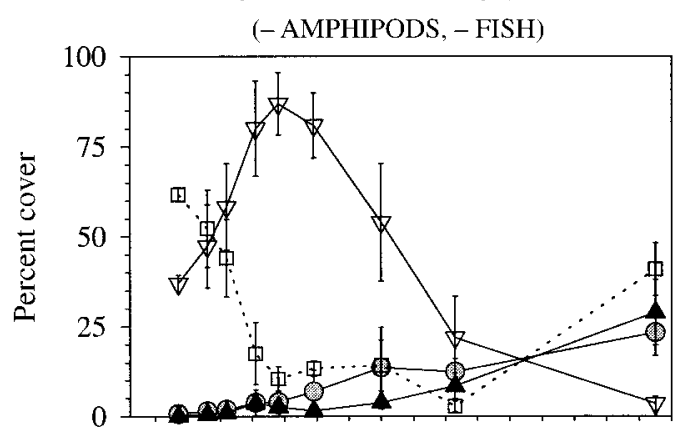

AMPHIPOD-DOMINATED

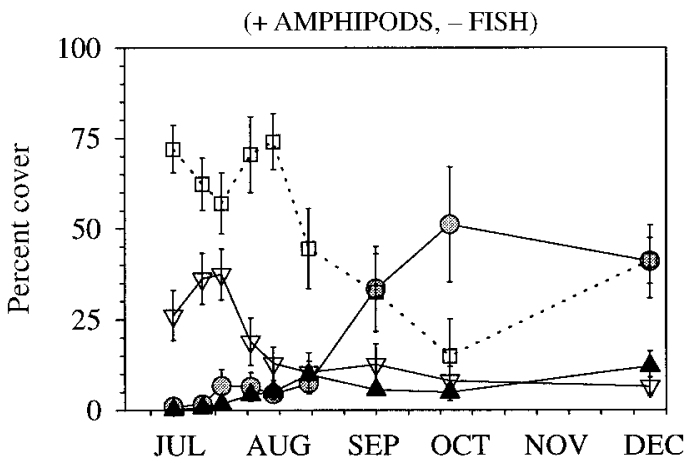

FISH-DOMINATED

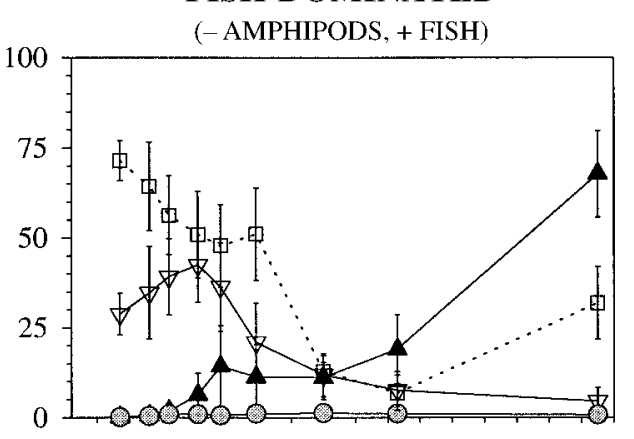

FISH and AMPHIPODS

(+ AMPHIPODS, + FISH)

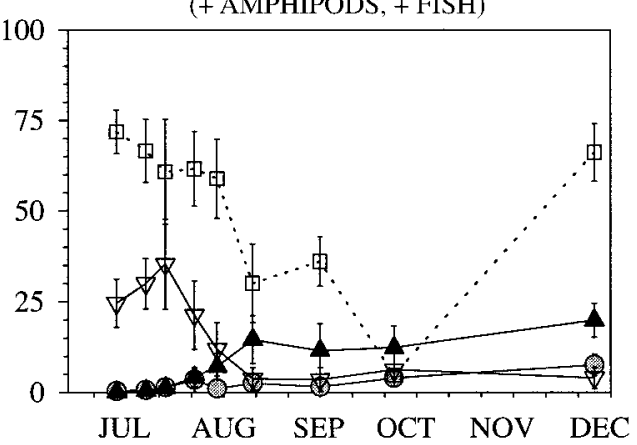

FIG. 2. Successional patterns as percent cover (mean $\pm 1 \mathrm{SE}$ ) of the dominant groups of benthic algae, and bare space, in the four experimental grazer treatments. Data shown are from the unmanipulated control (noncompetitor removal) blocks only $(n=4)$. Cover totals $100 \%$ in many cases because of high cover of a detritus/microbial coating of unknown origin. All treatments included some isopods (Paracerceis caudata) and snails (Diastoma varium), but the "grazer-removal" treatment contained no fish and very few amphipods (Fig. 8).

Because in this case other grazers are present in both the normal and deletion treatments, the net effect measures the grazer's total impacts on the target algal group including those resulting from interactions with effects of other grazers. In other words, the isolated effect of a grazer measures the impact of adding that grazer to an algal assemblage, whereas the net effect measures the impact of deleting that grazer from an intact community.

\section{RESULTS}

\section{Evaluation of insecticide effects}

Exposure to Sevin had a rapid and severe effect on the amphipod Ampithoe longimana. When exposed to the insecticide at a concentration of $1 \mu \mathrm{L} / \mathrm{L}$ in the laboratory assay, all individuals were obviously moribund, i.e., lying in unnatural positions with little movement, within 2-3 $\mathrm{min}$. In the six replicate groups exposed to insecticide, all individuals died by the end of the 60min observation period; the average time ( $\pm 1 \mathrm{SE})$ until all individuals died was $11.4 \pm 4.5 \mathrm{~min}$. All amphipods in untreated control bowls were active and apparently healthy at the end of the experiment. The difference in survival between Sevin and control treatments was significant $(P<0.005$, Mann-Whitney $U$ test). Similarly, when the mesocosm tanks were treated with Sevin, dead and dying amphipods were conspicuous by the end of the treatment.

In contrast, the insecticide treatment had no effect on survival or growth of spottail pinfish during the 39$\mathrm{d}$ experiment. All fish survived the experiment except for two that leapt out of their tanks and were lost; fish in those pairs were excluded from the analysis, resulting in a total sample of 13 pairs. When fish were 
GREEN ALGAE

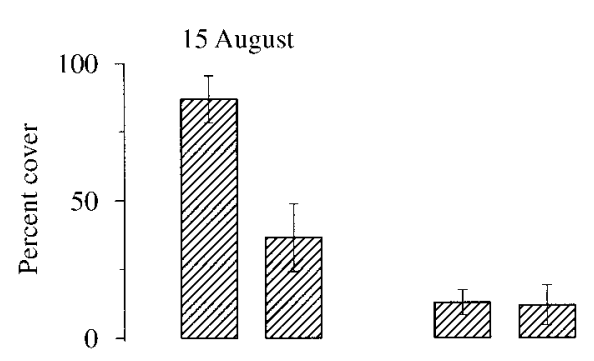

RED ALGAE

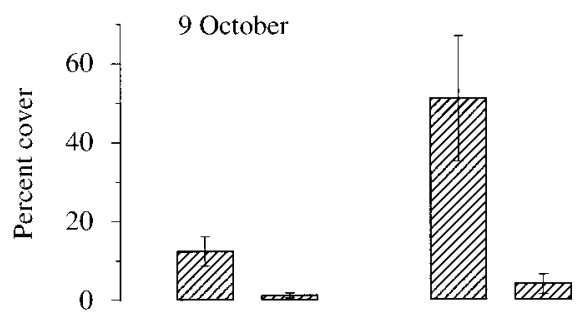

BROWN ALGAE

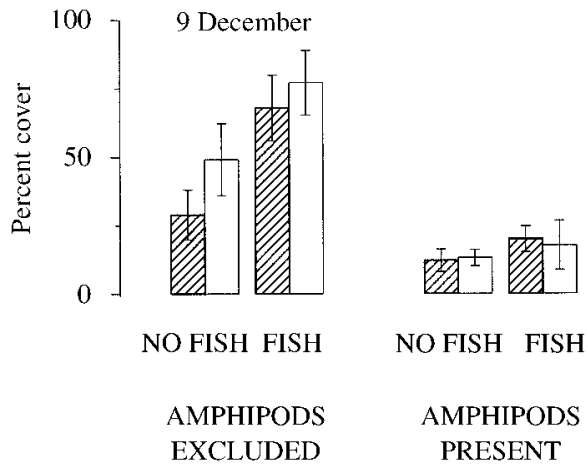

FIG. 3. Impacts of different grazer treatments on cover (mean $\pm 1 \mathrm{SE}$ ) of the three major algal groups for the date on which each group peaked in overall abundance. For brown algae, data from competitor-removal (hatched bars) and control (open bars) blocks are shown separately; for other algal taxa, data are shown only for control blocks. See Table 3 for statistical analysis.

paired by size and food ration, mean percentage change in standard length of control fish was $20.0( \pm 2.8) \%$ and did not differ from change for Sevin-treated fish (17.1 $\pm 3.2 \%, P=0.16$, paired-sample $t$ test).

\section{Development of Algal Assemblages}

Grazer impacts on benthic succession: general patterns.-Over the course of the five-month experiment, the mesocosm tanks developed a diverse assemblage of algae, sessile invertebrates, and mesograzers. In all treatments, the benthic community was eventually dominated by seaweeds. These communities differed markedly, however, among treatments. Where both fish and amphipods were removed, fast-growing, structur- ally simple green algae (primarily Enteromorpha sp. and Cladophora ruchingeri) rapidly covered most available space and held it throughout much of the five months of the experiment (Fig. 2). Green algae in this treatment covered at least twice as much space (87 \pm 9\% on 15 August) as in any other treatment (maximum of $43 \pm 10 \%$ on any date), dominated the community longer, and were the most abundant algal type through the October sampling date in the grazer-removal treatment. Indeed the data for percent cover substantially underestimate the differences in algal biomass among treatments since green algae in treatments with grazers were invariably cropped to a turf only a few millimeters high, whereas Cladophora tufts in the treatment lacking grazers reached lengths up to $\sim 200 \mathrm{~mm}$ (J. E. Duffy, personal observation). Red algae in the grazer-removal treatment reached a maximum coverage of $23 \pm 6 \%$ at the end of the experiment in December. Brown algae achieved similar cover only on the final date. Thus, rapidly growing green algae appear to be the competitive dominants in this system for most of the growing season, at least in the short term (less than one year).

In the fish-dominated treatment, where amphipods were suppressed by insecticide (see Results: Mesograzer abundance), blocks developed a seaweed assemblage quite similar to that found locally on hard substrata: green algae dominated initially but declined in August, after which brown algae (primarily Dictyota menstrualis and Padina gymnospora early in the season, and Sargassum filipendula after September) began to increase in cover (Fig. 2). By the end of the experiment coverage by browns averaged $68 \pm 12 \%$ of space. Red algae never grew much larger than the sporeling stage in the fish-dominated treatment.

Blocks exposed only to mesograzers ("amphipoddominated") developed markedly different communities than did any of the other three treatments. In August, after the initial bloom of greens that occurred in all treatments, red seaweeds (primarily Hypnea musciformis and Chondria dasyphylla) increased rapidly and maintained dominance for the duration of the experiment (Fig. 2). Thus, these red macroalgae achieved appreciable cover only where amphipods were present and fish were absent.

Blocks exposed to both fish and amphipods developed a community somewhat similar to that where only fish were present, but with substantially lower total cover (Fig. 2). Blocks were colonized initially by the green algae Enteromorpha and Cladophora, which gradually gave way to dominance by browns, primarily Sargassum filipendula. At the end of the experiment, however, browns averaged only $20 \pm 5 \%$ cover, less than one-third of their cover in the fish-only treatment. As in the latter treatment, coverage by reds was very low, never exceeding $8 \pm 3 \%$. A substantial proportion of space remained bare throughout, with $66 \%$ of space unoccupied at the end of the experiment.

Grazer impacts on benthic succession: statistical 
TABLE 3. Results of split-plot analyses of variance testing differences among grazer treatments in cover of the three major algal groups on dates at which each reached its highest overall cover, and in total benthic biomass at the end of the experiment.

\begin{tabular}{|c|c|c|c|c|c|}
\hline $\begin{array}{l}\text { Response variable } \dagger \\
\text { and source }\end{array}$ & df & SS & MS & $F \ddagger$ & $P$ \\
\hline \multicolumn{6}{|l|}{ Green algal cover ( 15 Aug) } \\
\hline Insecticide & 1 & 9687 & 9687 & 25.85 & 0.0023 \\
\hline Tank(Insecticide) & 6 & 2248 & 375 & & \\
\hline Fish & 1 & 2660 & 2660 & 11.77 & 0.014 \\
\hline Fish $\times$ Insecticide & 1 & 2448 & 2448 & 10.83 & 0.017 \\
\hline Tank $\times$ Fish $($ Insecticide $)$ & 6 & 1356 & 226 & & \\
\hline \multicolumn{6}{|l|}{ Red algal cover (9 Oct) } \\
\hline Insecticide & 1 & 3.39 & 3.39 & 4.86 & 0.07 \\
\hline Tank(Insecticide) & 6 & 4.18 & 0.70 & & \\
\hline Fish & 1 & 18.13 & 18.13 & 33.90 & 0.001 \\
\hline Fish $\times$ Insecticide & 1 & 0.27 & 0.27 & 0.50 & 0.50 \\
\hline Tank $\times$ Fish (Insecticide) & 6 & 22.12 & 3.69 & & \\
\hline \multicolumn{6}{|l|}{ Brown algal cover ( 9 Dec) } \\
\hline Insecticide & 1 & 4195 & 4195 & 8.58 & 0.026 \\
\hline Tank(Insecticide) & 6 & 2934 & 2934 & & \\
\hline Fish & 1 & 2192 & 2192 & 55.28 & 0.0003 \\
\hline Fish $\times$ Insecticide & 1 & 978 & 978 & 24.66 & 0.0025 \\
\hline Tank $\times$ Fish(Insecticide) & 6 & 237 & 40 & & \\
\hline \multicolumn{6}{|c|}{ Total benthic biomass (9 Dec) } \\
\hline Insecticide & 1 & 1.15 & 1.15 & 1.59 & 0.25 \\
\hline Tank(Insecticide) & 6 & 4.35 & 0.72 & & \\
\hline Fish & 1 & 0.012 & 0.012 & 0.12 & 0.74 \\
\hline Fish $\times$ Insecticide & 1 & 1.04 & 1.04 & 10.41 & 0.018 \\
\hline Tank $\times$ Fish $($ Insecticide $)$ & 6 & 2.83 & 0.47 & & \\
\hline
\end{tabular}

analysis.-The divergent impacts of fish and amphipods can be seen most readily on the dates when each of the three major algal groups reached its highest abundance (Fig. 3, Table 3). On 15 August, when green algae reached highest overall cover across treatments, both fish $(P=0.014$, split-plot ANOVA $)$ and amphipods $(P=0.002)$ each strongly reduced green algal cover, with the interaction $(P=0.017)$ reflecting the much greater impact of each grazer where the other was absent. On 9 October, when red algae peaked, there was a strongly negative effect of fish $(P=0.001)$ on red cover, reflecting the near absence of red algae in both treatments containing fish, whereas the positive effect of amphipods was marginal $(P=0.070)$. At the end of the experiment on 9 December, brown algal cover was lower in the presence of amphipods $(P=$ $0.026)$, and enhanced by fish $(P=0.0003)$, with the interaction $(P=0.002)$ again reflecting the greater impact of fish where amphipods were absent. That the reduced cover of browns in amphipod treatments was a result of grazing is supported by observations of extensive grazing damage to Sargassum fronds in these treatments (Fig. 4, Table 4, see Results: Grazer impacts). Fish and amphipod effects on total benthic biomass, which was dominated by brown algae, were similar to those for brown cover (Fig. 5, Table 3). In this case mesograzers alone had little effect on total benthic biomass, and fish alone increased benthic biomass, whereas fish and amphipods together strongly depressed benthic biomass (fish $\times$ amphipod interaction, $P=0.018)$.

We tested grazer impacts on benthic species richness and diversity, as measured by Simpson's $1-\lambda$ (Lande 1996), on the three dates on which the major algal groups reached maximum abundance (15 August, 9 October, 9 December). Fish depressed both species richness and diversity of benthic organisms on 9 October, and species richness on 9 December, whereas amphipods had no effect on species diversity on any of the three dates tested (Table 5).

Competition among seaweeds.-Our results provide equivocal support for the hypothesis that competition from red and green algae depresses brown algal dominance in the absence of fish. On the one hand, substratum blocks experimentally cleared of reds and greens showed no significant enhancement of brown macroalgal cover in any of the grazer treatments (Fig. 6). Specifically, paired-sample $t$ tests comparing brown cover on the control and competitor-removal blocks in a compartment were performed for each of the 36 datetreatment combinations, and none of these tests approached the Bonferroni-corrected significance level for multiple tests. These results argue at least that competitive release alone does not explain fish-mediated 


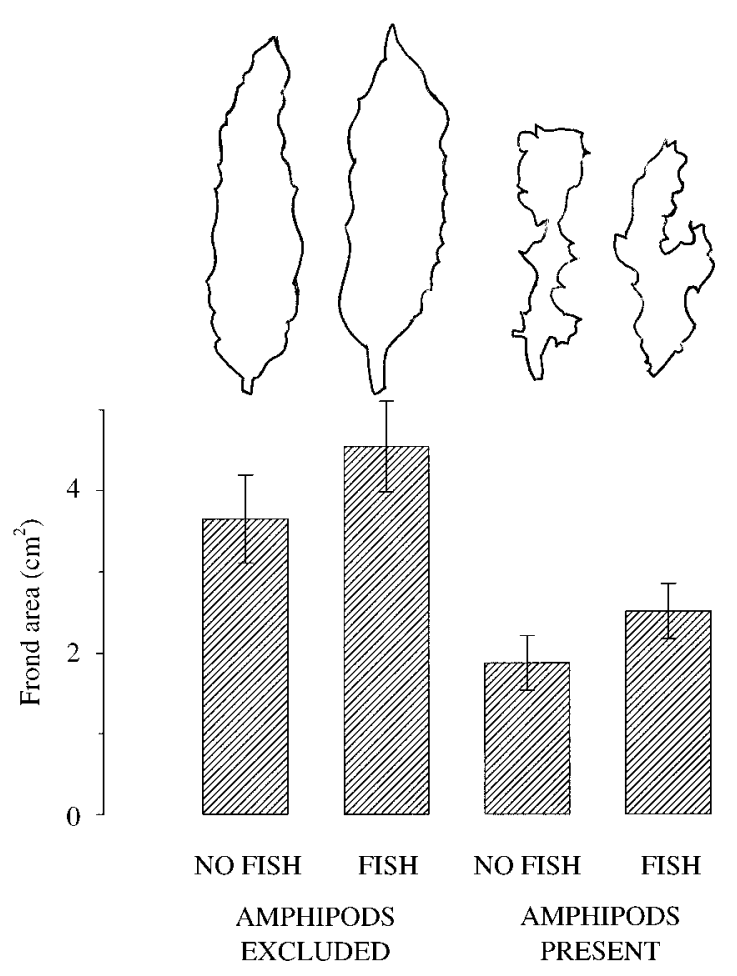

FIG. 4. Impacts of different grazer treatments on individual frond area (mean $\pm 1 \mathrm{SE}$ ) of Sargassum filipendula plants harvested from substratum blocks at the end of the experiment. A representative frond from that treatment is shown above each bar. See Table 4 for statistical analysis.

dominance by brown algae. On the other hand, despite the lack of statistical significance, brown algal cover in the absence of grazers was consistently, if only slightly, higher where red and green algae were removed for five months (Figs. 3 and 7).

\section{Mesograzer abundance in the tanks}

Animal assemblages associated with brown algae in the tanks during September (Table 6) included many of the same taxa found on brown seaweeds at local field sites (Duffy 1989, 1990). Somewhat surprisingly, neither periodic applications of insecticide nor the presence of spottail pinfish significantly reduced total abundance of mobile epifaunal animals, or total abundance of mesograzers, associated with brown algae in the tanks (Fig. 7, Table 7). The lack of treatment effects
TOTAL BIOMASS

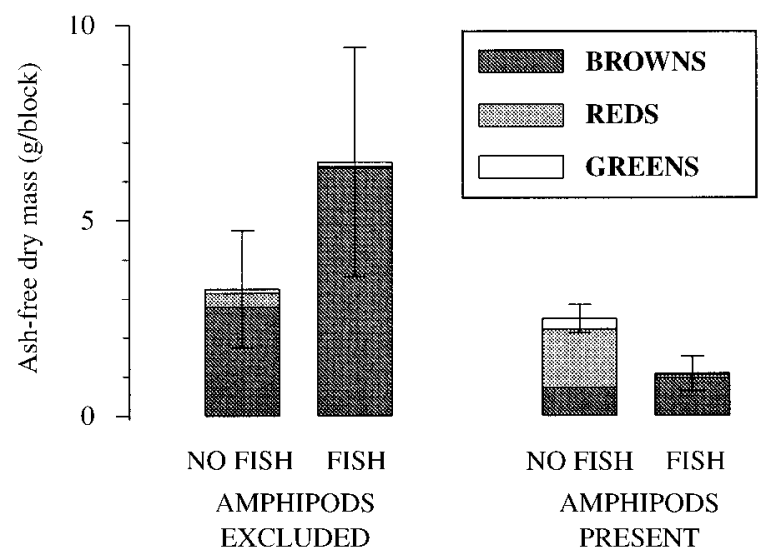

FIG. 5. Impacts of different grazer treatments on biomass of the major taxa of benthic organisms occupying substratum blocks (unmanipulated controls only) at the end of the experiment in December. Biomass of sessile animals was negligible $(<0.04 \mathrm{~g}$ in all treatments $)$. Error bars show $\pm 1 \mathrm{SE}$ for total summed biomass. See Table 3 for statistical analysis.

on epifaunal density is attributable in large part to the dominance of the mesograzer assemblage by the gastropod Diastoma varium (48\% of total mobile epifaunal individuals collected), which was unaffected by either fish or insecticide (Fig. 8, Table 8). In contrast, insecticide was almost completely effective at suppressing grazing amphipods, including Ampithoe longimana and Dulichiella appendiculata (Fig. 8, Table 8). Although animals were sampled $19 \mathrm{~d}$ after the most recent application of insecticide to the tanks, a total of only 48 grazing amphipods was collected from algal samples in all insecticide-treated compartments, compared with 1678 from samples in the untreated compartments (Table 6), a 35-fold difference. Finally, insecticide treatments actually increased densities of the isopod Paracerceis caudata (Fig. 8, Table 8), perhaps by relaxing competition from amphipods, or providing more favorable algal foods. The concentration of Sevin we used was the minimum that we judged effective at killing amphipods, as determined in laboratory experiments prior to the mesocosm study. Apparently this concentration was not sufficient to kill isopods. For the four most abundant grazer species, there were few ob-

TABLE 4. Results of split-plot analysis of variance testing differences among grazer treatments in mean individual frond area of Sargassum filipendula plants harvested at the end of the experiment.

\begin{tabular}{llrrrr}
\hline \hline \multicolumn{1}{c}{ Source } & df & SS & MS & \multicolumn{1}{c}{$F$} & $P$ \\
\hline Insecticide & 1 & 14.54 & 14.54 & 9.38 & $\mathbf{0 . 0 2 2}$ \\
Tank(Insecticide) & 6 & 9.30 & 1.55 & & \\
Fish & 1 & 2.36 & 2.36 & 18.40 & $\mathbf{0 . 0 0 5 1}$ \\
Fish $\times$ Insecticide & 1 & 0.07 & 0.07 & 0.52 & 0.50 \\
Tank $\times$ Fish(Insecticide) & 6 & 0.77 & 0.13 & & \\
\hline
\end{tabular}

Notes: $F$ tests were calculated as in Table 3. $P$ values $<0.05$ are indicated in bold. 
TABLE 5. Results of split-plot analyses of variance testing differences among grazer treatments in benthic species richness and diversity (Simpson's 1- $\lambda$ ) on dates at which each of the major algal groups reached its highest overall cover in the experiment.

\begin{tabular}{|c|c|c|c|c|c|}
\hline $\begin{array}{l}\text { Response variable } \dagger \\
\text { and source }\end{array}$ & df & ss & MS & $F$ & $P$ \\
\hline \multicolumn{6}{|l|}{ Species richness (15 Aug) } \\
\hline Insecticide & 1 & 3.06 & 3.06 & 0.50 & 0.50 \\
\hline Tank(Insecticide) & 6 & 36.44 & 6.07 & & \\
\hline Fish & 1 & 5.06 & 5.06 & 3.50 & 0.11 \\
\hline Fish $\times$ Insecticide & 1 & 4.00 & 4.00 & 2.76 & 0.15 \\
\hline Tank $\times$ Fish(Insecticide) & 6 & 8.69 & 1.45 & & \\
\hline \multicolumn{6}{|l|}{ Diversity (15 Aug) } \\
\hline Insecticide & 1 & 0.000240 & 0.000240 & 0.01 & 0.93 \\
\hline Tank(Insecticide) & 6 & 0.181 & 0.0301 & & \\
\hline Fish & 1 & 0.00960 & 0.00960 & 0.44 & 0.53 \\
\hline Fish $\times$ Insecticide & 1 & 0.0337 & 0.0337 & 1.55 & 0.26 \\
\hline Tank $\times$ Fish(Insecticide) & 6 & 0.130 & 0.0217 & & \\
\hline \multicolumn{6}{|l|}{ Species richness (9 Oct) } \\
\hline Insecticide & 1 & 0.25 & 0.25 & 0.09 & 0.77 \\
\hline Tank(Insecticide) & 6 & 16.50 & 2.75 & & \\
\hline Fish & 1 & 45.56 & 45.56 & 12.36 & 0.013 \\
\hline Fish $\times$ Insecticide & 1 & 0.56 & 0.56 & 0.15 & 0.71 \\
\hline Tank $\times$ Fish(Insecticide $)$ & 6 & 22.12 & 3.69 & & \\
\hline \multicolumn{6}{|l|}{ Diversity (9 Oct) } \\
\hline Insecticide & 1 & 0.00107 & 0.00107 & 0.02 & 0.88 \\
\hline Tank(Insecticide) & 6 & 0.262 & 0.0437 & & \\
\hline Fish & 1 & 0.140 & 0.140 & 9.34 & 0.022 \\
\hline Fish $\times$ Insecticide & 1 & 0.000636 & 0.000636 & 0.04 & 0.84 \\
\hline Tank $\times$ Fish(Insecticide) & 6 & 0.0903 & 0.0903 & & \\
\hline \multicolumn{6}{|l|}{ Species richness (9 Dec) } \\
\hline Insecticide & 1 & 0.39 & 0.39 & 0.18 & 0.69 \\
\hline Tank(Insecticide) & 6 & 13.34 & 2.22 & & \\
\hline Fish & 1 & 8.26 & 8.26 & 23.69 & 0.0028 \\
\hline Fish $\times$ Insecticide & 1 & 1.27 & 1.27 & 3.63 & 0.11 \\
\hline Tank $\times$ Fish(Insecticide) & 6 & 2.09 & 0.35 & & \\
\hline \multicolumn{6}{|l|}{ Diversity (9 Dec) } \\
\hline Insecticide & 1 & 0.0411 & 0.0411 & 2.63 & 0.16 \\
\hline Tank(Insecticide) & 6 & 0.0937 & 0.0156 & & \\
\hline Fish & 1 & 0.0411 & 0.0411 & 2.19 & 0.19 \\
\hline Fish $\times$ Insecticide & 1 & 0.0000556 & 0.0000556 & 0.00 & 0.96 \\
\hline Tank $\times$ Fish(Insecticide) & 6 & 0.113 & 0.0188 & & \\
\hline
\end{tabular}

vious differences in density among the three brown algal species sampled.

Thus, the insecticide treatment in this experiment excluded amphipods specifically, and did not suppress numbers of the dominant gastropod and isopod. Whereas $D$. varium dominated insecticide treatments, A. longimana dominated in the absence of insecticide, comprising $44 \%$ of all mobile epifaunal individuals in insecticide-free treatments, regardless of the presence of fish (Table 6, Fig. 8). As was true for seaweeds, the "species" richness (some animals were identified only to higher taxon) of animals associated with algae was reduced by fish, whereas insecticide had no such effect (Fig. 7, Table 7).

\section{Laboratory feeding assays}

Of the six epifaunal species examined, only two fed appreciably on macroalgae in the laboratory assay (Fig.
9). In this assay significant consumption was detected by comparing mass loss of portions from the same algal thallus exposed, vs. unexposed, to grazers using pairedsample t tests; significance values were corrected across the seven separate algal species offered to each grazer species using the sequential Bonferroni procedure (Rice 1989). The amphipod Ampithoe longimana fed heavily on all species offered except for the red alga Chondria; it was the only grazer species that fed significantly on Sargassum, the dominant brown seaweed at out site. The isopod Paracerceis caudata also consumed significant amounts of the red alga Hypnea and the brown algae Padina and Dictyota. The amphipods Dulichiella appendiculata and Elasmopus levis each consumed relatively small but significant amounts of some macroalgal species. The two gastropods, Diastoma varium and Anachis avara, did not consume significant quantities of any of the algal species offered. 


\section{UNDISTURBED}

- REDS AND GREENS REMOVED
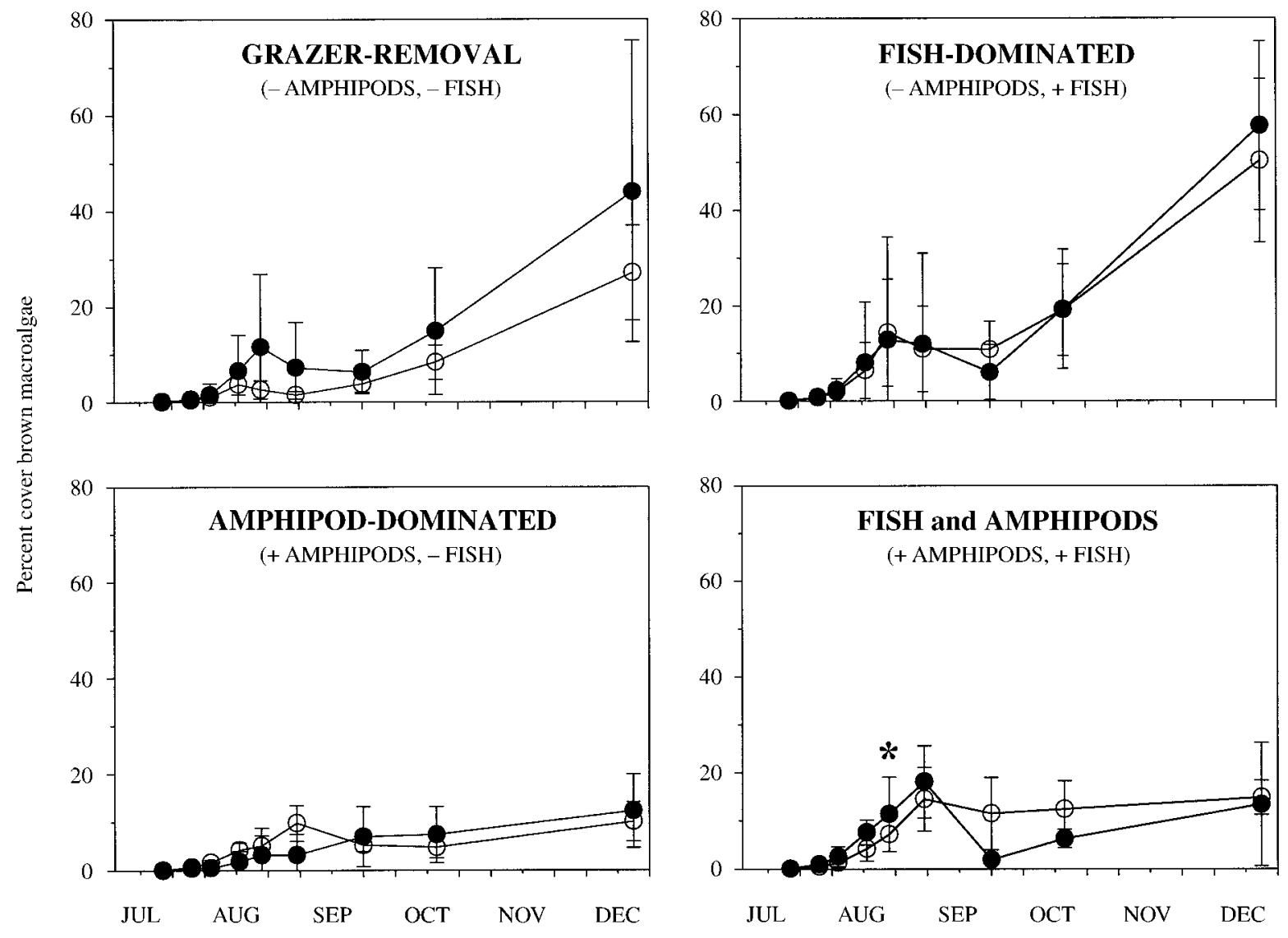

FIG. 6. Results of experimental treatments testing for competitive suppression of brown macroalgae by red and green algae. Separate paired $t$ tests comparing the cover of brown algae on control vs. removal blocks within the same compartment were conducted for each treatment/date combination; of these 36 tests, only one (denoted by *) was significant at the nominal $\alpha$ value of 0.05 , and none approached significance at the Bonferroni-corrected $\alpha$ for the entire set of tests.

\section{Grazer impacts on brown seaweeds}

Mesocosm grazing assays.-Overall, brown macroalgae deployed in the tanks fared poorly in treatments exposed to amphipods. Browns retrieved from the amphipod-exposed treatments often bore extensive amphipod grazing scars, particularly in the amphipoddominated treatment. Growth of brown seaweeds deployed for $8 \mathrm{~d}$ in the tanks was fairly consistently lower (often negative) in treatments with amphipods, but was never affected negatively by the presence of fish (Fig. 10, Table 9). Separate split-plot ANOVAs for each of the three brown algal species showed that amphipods reduced growth of Sargassum $(P<0.001)$ and Padina $(P=0.042)$ in August, the trend for Dictyota in August being obscured by a fish $\times$ amphipod interaction $(P=$ $0.004)$. In September, amphipods reduced growth of Dictyota $(P=0.003)$ and Padina $(P=0.014)$, with a similar but nonsignificant trend $(P=0.11)$ for Sargassum. Growth of Dictyota was enhanced by the presence of fish in September $(P=0.021)$.

To examine the effect of grazers on brown seaweeds in aggregate, we pooled mass changes for all three species within a compartment. In August, amphipods $\left(F_{1,6}=10.63, P=0.017\right)$, but not fish $\left(F_{1,6}=1.29\right.$, $P=0.30)$, affected algal mass; the interaction $\left(F_{1,6}=\right.$ $18.40, P=0.005)$ revealed that reduction in growth of brown algae by amphipods was more pronounced in the absence of fish. In September, amphipods again reduced brown algal growth $\left(F_{1,6}=25.95, P=0.002\right)$, whereas fish had no effect $\left(F_{1,6}=1.72, P=0.24\right)$, and there was no interaction $\left(F_{1,6}=3.38, P=0.12\right)$.

Sargassum leaf damage measurements.-Fronds of Sargassum harvested from the blocks at the end of the experiment were extensively damaged by grazing scars 

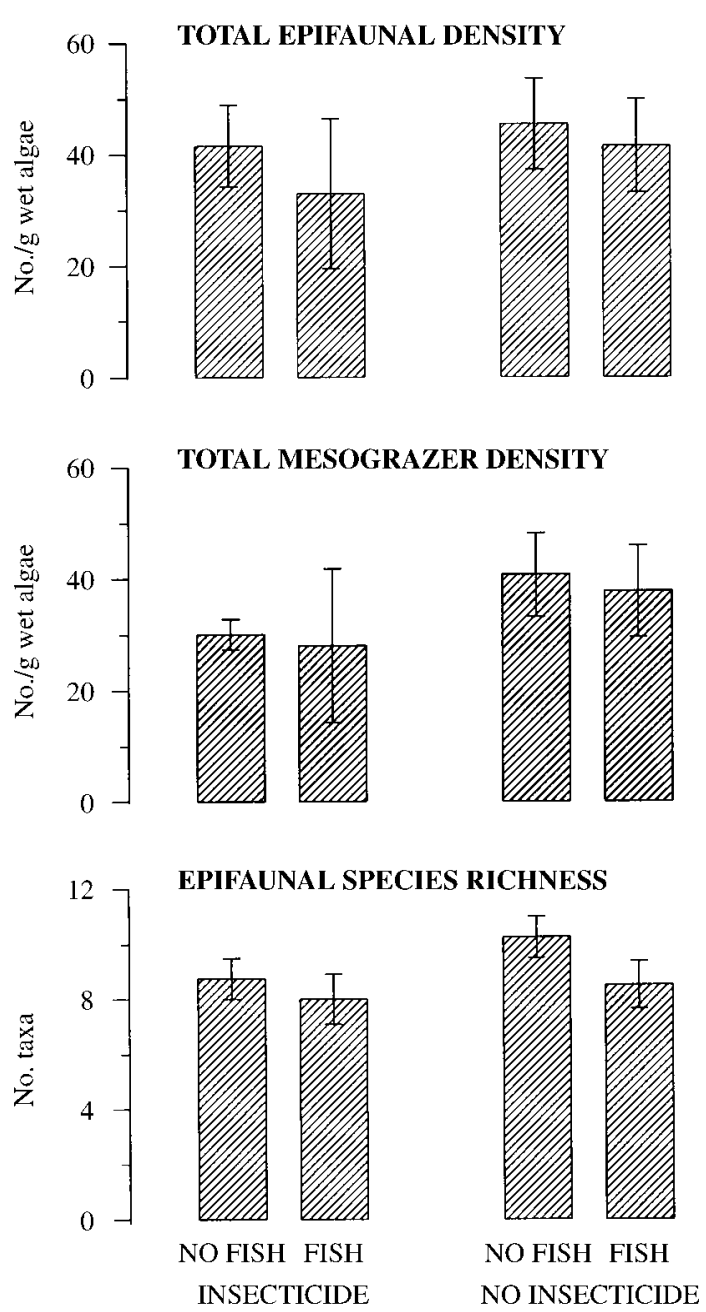

FIG. 7. Effects of insecticide treatment and fish on abundance and species richness (mean $\pm 1 \mathrm{SE}$ ) of epifauna associated with brown algae deployed in the mesocosm tanks in September. Data were pooled from the three seaweeds (Dictyota, Sargassum, and Padina) deployed during the September grazing assay, which ended $19 \mathrm{~d}$ after the most recent insecticide application. Animal densities were measured on the same plants from which grazing losses were measured (Fig. 10). Total epifauna includes all animals found on the plants; total mesograzers includes all species judged from this and previous studies to be herbivorous (see Table 6). See Table 7 for statistical analysis.

in treatments containing amphipods (Fig. 4). In the amphipod-dominated treatment, in particular, many Sargassum stipes bore few remaining fronds. Of the remaining fronds, mean individual frond area was strongly reduced by amphipods, by $49 \%$ on average ( $P$ $=0.022$, split-plot ANOVA) and increased by an average of $28 \%$ by fish $(P=0.005)$, with no interaction between the two grazers $(P=0.500$, Fig. 4$)$.

\section{Comparing impacts of fish and amphipods}

The relative impacts of spottail pinfish and grazing amphipods on the algal assemblage differed consid-
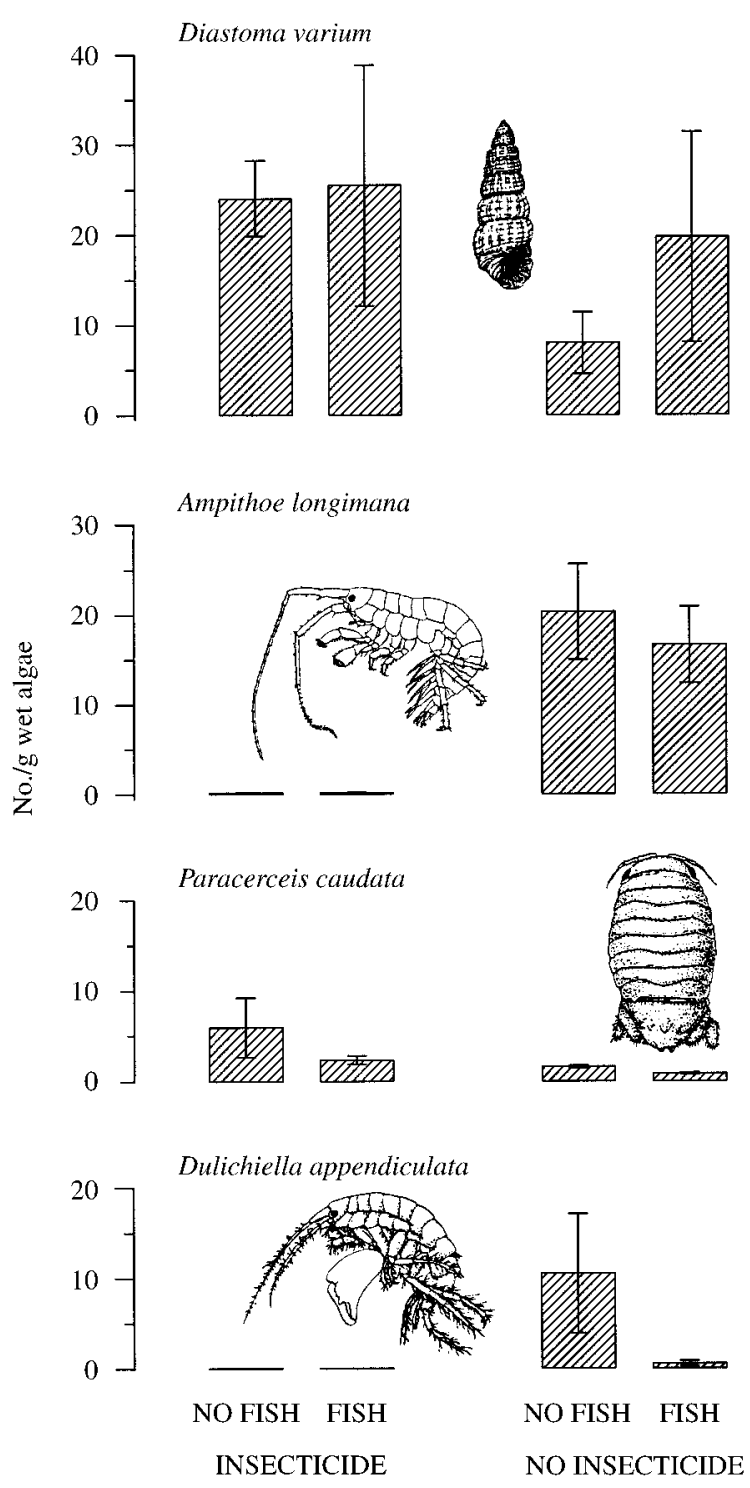

FIG. 8. Effects of insecticide treatment and fish on densities (mean $\pm 1 \mathrm{SE}$ ) of the four most abundant mesograzer species associated with brown algae deployed in the mesocosm tanks in September. These are also the four grazer species found to consume significant amounts of algae in laboratory assays (see Fig. 10). See Table 8 for statistical analysis.

erably depending on how they were calculated (Fig. 11). Comparison is most straightforward for the "isolated effects," which compare treatments with one grazer type vs. the treatment with no grazers (-fish/ -amphipods). Perhaps surprisingly, the raw, collective effects of amphipods were greater than those of fish for both green and red algae, and were approximately half as large as those of fish for brown algae (Fig. 11). These collective effects of amphipods result in part from their high density in the - fish/+ amphipods treatment, an analog of field situations where fish predation 

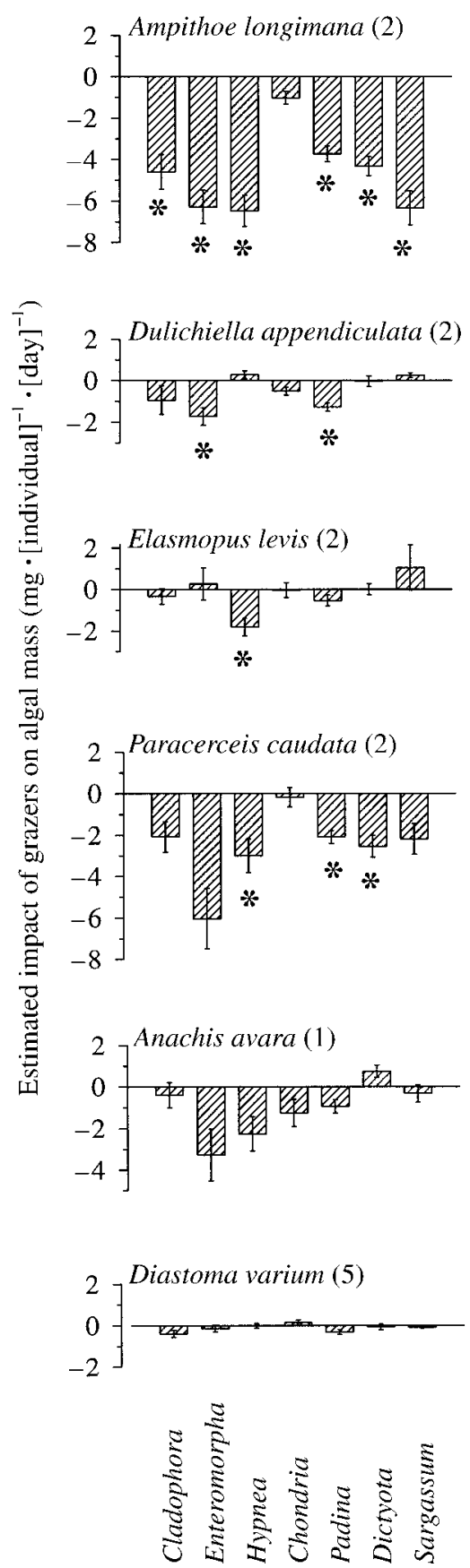

FIG. 9. Grazing impacts of common epifaunal invertebrates on seven algal species in the laboratory. Grazing impacts were calculated by subtracting the mass change in algal portions exposed to animals from that of unexposed (control) portions from the same individual thallus. A significant impact of grazing was inferred from paired $t$ tests comparing exposed and unexposed portions, with the $\alpha$ level adjusted to 0.05 over all seven algal species via the sequential Bonferroni procedure (Rice 1989). The number of individuals per replicate is in parentheses. is negligible. As expected, the per capita effects of fish were two to three orders of magnitude greater than those of amphipods, reflecting a similarly large difference in body mass between the two grazer types. In contrast, when expressed per unit grazer biomass, the isolated effect of amphipods was greater than that of fish for all algal response variables, and substantially so for red and green algal cover (Fig. 11).

The net effect of a grazer in our experiment is the difference in the response variable that results from removing that grazer from the normal community that includes both grazers. Thus, the net effect potentially includes interactions with the effects of the other grazer taxon. In contrast to the pattern for isolated effects, the net effects of amphipods were stronger than those of fish for brown algae and weaker for red algae, whether calculated on a collective or per-biomass basis (Fig. 11). These results suggest that amphipods can have dramatic impacts on benthic community organization even in the presence of fish.

\section{Discussion}

Our results demonstrate that grazing amphipods can produce impacts on benthic community organization that are comparable or greater in magnitude, but markedly different in kind, to the widely appreciated impacts of fishes. Specifically, both types of grazers strongly depressed cover of early-successional green algae, and both had comparably strong impacts on late-successional red and brown algae. But fish ultimately produced a benthic community dominated by brown macroalgae, similar to that occurring at undisturbed field sites in out area, whereas amphipods produced a community dominated by red macroalgae. Paralleling these patterns, exclusion of fishes from local field sites results in dominance by red algae, while brown algae dominate in the presence of fish (Miller and Hay 1996). Exclusion of both grazers in our mesocosm experiment resulted in a third community configuration in which the fast-growing, "ephemeral" green algae Entermorpha and Cladophora maintained dominance throughout much of the five-month experiment.

The main objective of this study was to assess experimentally the poorly understood role of mesograzers, and compare it with the well-documented importance of algal competition (Dayton 1975, 1985, Schiel and Foster 1986) and grazing by omnivorous fish (Hay 1986, Miller and Hay 1996) in organizing a seaweeddominated benthic community. Specifically, we sought to determine the mechanism for the finding that omnivorous fishes promote dominance by brown seaweeds, whereas reds prevail in the absence of fishes (Miller and Hay 1996; M. E. Hay, unpublished data). Our experiment was designed to distinguish between two distinct hypotheses for these results: (1) red and green algae released from fish grazing outcompete browns (the "competition hypothesis"), and (2) amphipods released from fish predation graze heavily on 
TABLE 6. Animals collected from brown seaweeds deployed in the mesocosm tanks during the September grazing experiment.

\begin{tabular}{lrrrr}
\hline \hline \multicolumn{1}{c}{ Taxon } & $\begin{array}{c}\text { Fish, } \\
\text { + Insecticide }\end{array}$ & $\begin{array}{c}\text { + Fish, } \\
\text { + Insecticide }\end{array}$ & $\begin{array}{c}\text { - Fish, } \\
\text { - Insecticide }\end{array}$ & $\begin{array}{c}\text { + Fish, } \\
\text { - Insecticide }\end{array}$ \\
\hline Diastoma varium $(\mathrm{G})$ & 1016 & 808 & 318 & 587 \\
Ampithoe longimana $(\mathrm{G})$ & 6 & 6 & 637 & 603 \\
Leptochelia sp. & 389 & 98 & 5 & 3 \\
Paracerceis caudata $(\mathrm{G})$ & 258 & 81 & 55 & 28 \\
Dulichiella appendiculata $(\mathrm{G})$ & 0 & 0 & 278 & 19 \\
Corophium spp. & 51 & 58 & 23 & 49 \\
Elasmopus levis & 0 & 0 & 74 & 51 \\
Costoanachis sp. & 8 & 12 & 37 & 16 \\
Caprella penantis $(\mathrm{G})$ & 34 & 2 & 3 & 4 \\
Astyris lunata & 4 & 8 & 2 & 4 \\
Erichthonius brasiliensis & 4 & 1 & 5 & 2 \\
Ampithoe marcuzii $(\mathrm{G})$ & 0 & 0 & 9 & 0 \\
Other gastropods & 2 & 4 & 0 & 0 \\
Polychaetes & 6 & 1 & 0 & 1 \\
Cerapus tubularis & 0 & 0 & 0 & 0 \\
Paracaprella tenuis & 0 & 0 & 1 & 0 \\
Stenothoe sp. & 1 & 0 & 0 & 1241 \\
Crab megalopa & 1 & 0 & 0 & 654 \\
Total grazers & 1314 & 897 & 1301 & 1368 \\
Total crustacean grazers & 298 & 89 & 983 & 0 \\
Total animals & 1782 & 1079 & 1450 & \\
\hline
\end{tabular}

Notes: The total numbers of each taxon collected from all three algal species combined $(n$ $=4$ of each) are presented, by treatment. Analyses of treatment effects on particular taxa are presented in Figs. 8 and 9. Taxonomy follows Ruppert and Fox (1988). G = grazer.

browns (the "trophic cascade hypothesis"). We conclude that our data support important roles for both amphipod grazing and possibly algal competition in suppressing brown algal dominance where fish are absent. Several lines of evidence implicate the importance of amphipod grazing. First, brown macroalgae deployed in the tanks generally lost more mass, or gained mass more slowly, in amphipod-exposed treatments than in treatments without amphipods (Fig. 10, Table 9), corroborating amphipod feeding patterns seen in laboratory assays (Fig. 9). Second, browns that recruited naturally onto blocks in the amphipod-dominated treatments bore extensive scars from amphipod grazing that reduced blade size (Fig. 4, Table 4) and, in some cases, reduced Sargassum plants to bare stipes. Third, exclusion of amphipods with insecticide substantially increased the cover and biomass of browns, particularly where fish were present (Figs. 2-5). In contrast, evidence for the role of algal competition is more indirect. Although weekly removal of red and green

TABLE 7. Results of split-plot analyses of variance testing differences among grazer treatments in epifaunal density and species richness in September.

\begin{tabular}{|c|c|c|c|c|c|}
\hline $\begin{array}{l}\text { Response variable } \\
\text { and source }\end{array}$ & df & SS & MS & $F$ & $P$ \\
\hline \multicolumn{6}{|l|}{ Total epifaunal density } \\
\hline Insecticide & 1 & 155 & 155 & 0.78 & 0.41 \\
\hline Tank(Insecticide) & 6 & 1191 & 198 & & \\
\hline Fish & 1 & 158 & 158 & 0.29 & 0.61 \\
\hline Fish $\times$ Insecticide & 1 & 22 & 22 & 0.04 & 0.85 \\
\hline Tank $\times$ Fish(Insecticide) & 6 & 3272 & 545 & & \\
\hline \multicolumn{6}{|l|}{ Total mesograzer density } \\
\hline Insecticide & 1 & 388 & 388 & 2.37 & 0.17 \\
\hline Tank(Insecticide) & 6 & 981 & 164 & & \\
\hline Fish & 1 & 32 & 32 & 0.07 & 0.80 \\
\hline Fish $\times$ Insecticide & 1 & 0.01 & 0.01 & 0.00 & 0.99 \\
\hline Tank $\times$ Fish(Insecticide) & 6 & 2893 & 482 & & \\
\hline \multicolumn{6}{|l|}{ Epifaunal species richness } \\
\hline Insecticide & 1 & 4.00 & 4.00 & 0.83 & 0.40 \\
\hline Tank(Insecticide) & 6 & 28.75 & 4.79 & & \\
\hline Fish & 1 & 6.25 & 6.25 & 10.00 & 0.020 \\
\hline Fish $\times$ Insecticide & 1 & 1.00 & 1.00 & 1.60 & 0.25 \\
\hline Tank $\times$ Fish(Insecticide) & 6 & 3.75 & 0.62 & & \\
\hline
\end{tabular}

Notes: $F$ tests were calculated as in Table 3. $P$ values $<0.05$ are indicated in bold. 
TABLE 8. Results of slit-plot analyses of variance testing differences among grazer treatments in density of the four most abundant mesograzer species in September.

\begin{tabular}{|c|c|c|c|c|c|}
\hline $\begin{array}{l}\text { Response variable } \\
\text { and source }\end{array}$ & df & ss & MS & $F$ & $P$ \\
\hline \multicolumn{6}{|l|}{ Diastoma varium } \\
\hline Insecticide & 1 & 896 & 896 & 0.16 & 0.70 \\
\hline Tank(Insecticide) & 6 & 33082 & 5513 & & \\
\hline Fish & 1 & 2393 & 2393 & 0.55 & 0.49 \\
\hline Fish $\times$ Insecticide & 1 & 4476 & 4476 & 1.02 & 0.35 \\
\hline Tank $\times$ Fish(Insecticide $)$ & 6 & 26345 & 4390 & & \\
\hline \multicolumn{6}{|l|}{ Ampithoe longimana } \\
\hline Insecticide & 1 & 15115 & 15115 & 22.53 & 0.0032 \\
\hline Tank(Insecticide) & 6 & 4026 & 671 & & \\
\hline Fish & 1 & 184 & 184 & 2.18 & 0.19 \\
\hline Fish $\times$ Insecticide & 1 & 184 & 184 & 2.19 & 0.19 \\
\hline Tank $\times$ Fish(Insecticide) & 6 & 505 & 84 & & \\
\hline \multicolumn{6}{|l|}{ Paracerceis caudata } \\
\hline Insecticide & 1 & 1.58 & 1.58 & 8.00 & 0.030 \\
\hline Tank(Insecticide) & 6 & 1.19 & 0.20 & & \\
\hline Fish & 1 & 0.63 & 0.63 & 2.40 & 0.17 \\
\hline Fish $\times$ Insecticide & 1 & 0.007 & 0.007 & 0.03 & 0.87 \\
\hline Tank $\times$ Fish(Insecticide $)$ & 6 & 1.57 & 0.26 & & \\
\hline \multicolumn{6}{|l|}{ Dulichiella appendiculata } \\
\hline Insecticide & 1 & 4.87 & 4.87 & 7.98 & 0.030 \\
\hline Tank(Insecticide) & 6 & 3.66 & 0.61 & & \\
\hline Fish & 1 & 2.12 & 2.12 & 5.70 & 0.054 \\
\hline Fish $\times$ Insecticide & 1 & 2.12 & 2.12 & 5.70 & 0.054 \\
\hline Tank $\times$ Fish(Insecticide) & 6 & 2.23 & 0.37 & & \\
\hline
\end{tabular}

Notes: $F$ tests were calculated as in Table 3. $P$ values $<0.05$ are indicated in bold.

\section{AUGUST}
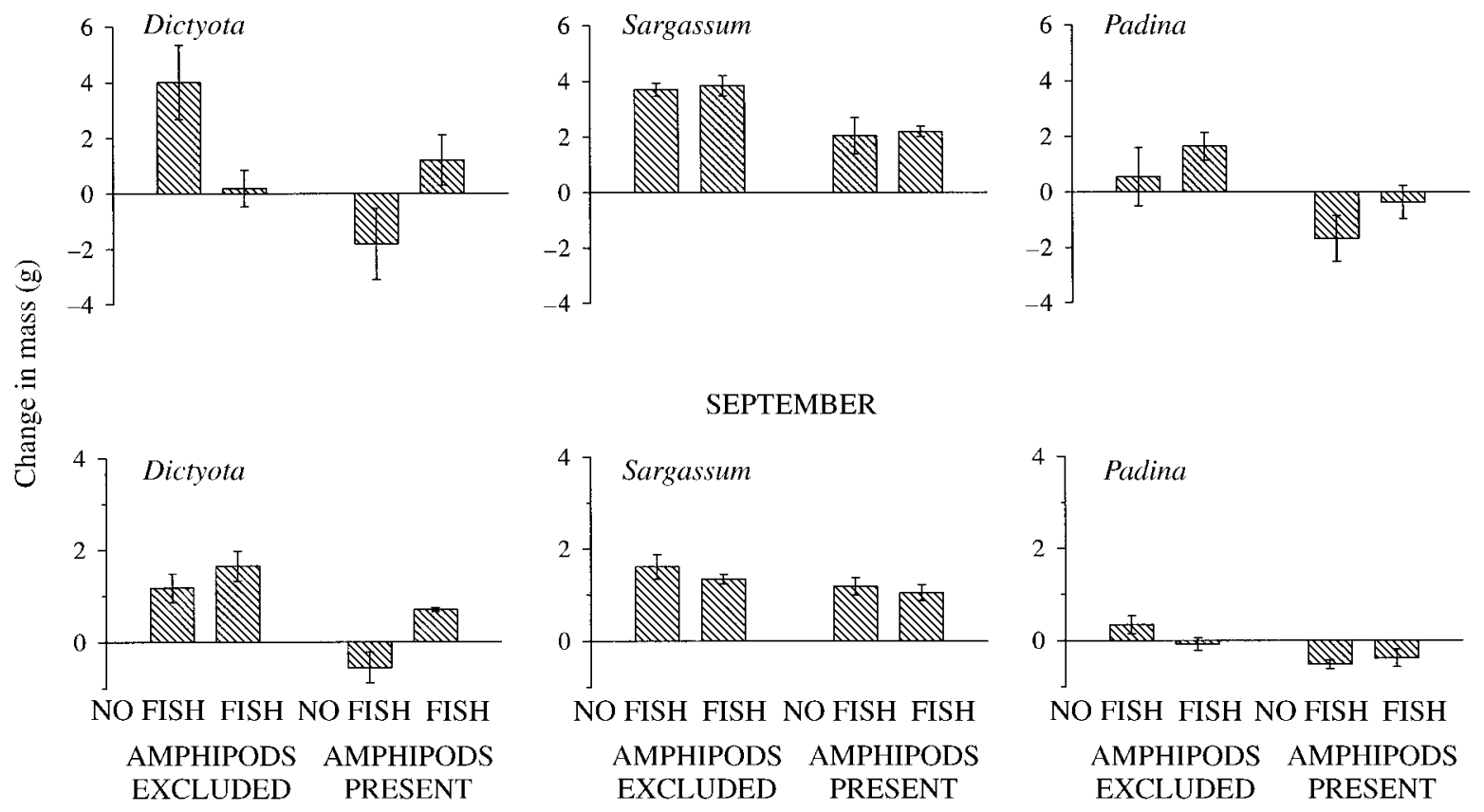

SEPTEMBER
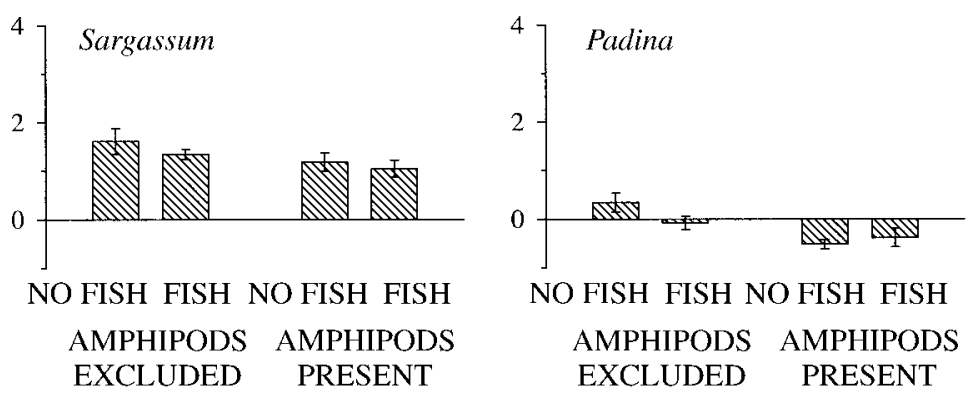

FIG. 10. Effects of grazer treatments on change in mass (mean $\pm 1 \mathrm{SE}$ ) of three brown seaweed species deployed for $7-$ $8 \mathrm{~d}$ in the mesocosm tanks. Results are shown for separate experiments in August (top) and September (bottom). See Table 9 for statistical analysis. 
TABLE 9. Results of split-plot analyses of variance testing differences among grazer treatments in mass change of three brown algal species deployed in the tanks at each of two time periods.

\begin{tabular}{|c|c|c|c|c|c|}
\hline $\begin{array}{l}\text { Response variable } \dagger \\
\text { and source }\end{array}$ & df & ss & MS & $F$ & $P$ \\
\hline \multicolumn{6}{|l|}{ Dictyota (August) } \\
\hline Insecticide & 1 & 23.14 & 23.14 & 3.32 & 0.12 \\
\hline Tank(Insecticide) & 6 & 41.77 & 6.96 & & \\
\hline Fish & 1 & 0.68 & 0.68 & 0.28 & 0.61 \\
\hline Fish $\times$ Insecticide & 1 & 46.84 & 46.84 & 19.58 & 0.0044 \\
\hline Tank $\times$ Fish(Insecticide) & 6 & 14.35 & 2.39 & & \\
\hline \multicolumn{6}{|l|}{ Sargassum (August) } \\
\hline Insecticide & 1 & 10.91 & 10.91 & 37.21 & 0.0009 \\
\hline Tank(Insecticide) & 6 & 1.76 & 0.29 & & \\
\hline Fish & 1 & 0.08 & 0.08 & 0.09 & 0.78 \\
\hline Fish $\times$ Insecticide & 1 & 0.00 & 0.00 & 0.00 & 0.99 \\
\hline Tank $\times$ Fish (Insecticide) & 6 & 5.90 & 0.98 & & \\
\hline \multicolumn{6}{|l|}{ Padina (August) } \\
\hline Insecticide & 1 & 18.00 & 18.00 & 6.60 & 0.042 \\
\hline Tank(Insecticide) & 6 & 16.36 & 2.73 & & \\
\hline Fish & 1 & 5.76 & 5.76 & 2.81 & 0.14 \\
\hline Fish $\times$ Insecticide & 1 & 0.05 & 0.05 & 0.02 & 0.89 \\
\hline Tank $\times$ Fish(Insecticide $)$ & 6 & 12.32 & 2.05 & & \\
\hline \multicolumn{6}{|l|}{ Dictyota (September) } \\
\hline Insecticide & 1 & 7.23 & 7.23 & 22.67 & 0.0031 \\
\hline Tank(Insecticide) & 6 & 1.91 & 0.32 & & \\
\hline Fish & 1 & 3.00 & 3.00 & 9.58 & 0.021 \\
\hline Fish $\times$ Insecticide & 1 & 0.60 & 0.60 & 1.91 & 0.22 \\
\hline Tank $\times$ Fish(Insecticide) & 6 & 1.88 & 0.31 & & \\
\hline \multicolumn{6}{|l|}{ Sargassum (September) } \\
\hline Insecticide & 1 & 0.53 & 0.53 & 3.59 & 0.11 \\
\hline Tank(Insecticide) & 6 & 0.89 & 0.15 & & \\
\hline Fish & 1 & 0.16 & 0.16 & 1.13 & 0.33 \\
\hline Fish $\times$ Insecticide & 1 & 0.02 & 0.02 & 0.12 & 0.74 \\
\hline Tank $\times$ Fish(Insecticide) & 6 & 0.87 & 0.15 & & \\
\hline \multicolumn{6}{|l|}{ Padina (September) } \\
\hline Insecticide & 1 & 1.35 & 1.35 & 11.76 & 0.014 \\
\hline Tank(Insecticide) & 6 & 0.69 & 0.11 & & \\
\hline Fish & 1 & 0.08 & 0.08 & 0.88 & 0.39 \\
\hline Fish $\times$ Insecticide & 1 & 0.31 & 0.31 & 3.41 & 0.11 \\
\hline Tank $\times$ Fish (Insecticide) & 6 & 0.55 & 0.09 & & \\
\hline
\end{tabular}

Notes: $F$ tests were calculated as in Table 3. $P$ values $<0.05$ are indicated in bold. $\dagger$ Month in parentheses.

algae from substratum blocks failed to enhance brown algal cover significantly, there was a slight but consistent trend toward higher brown algal cover on competitor-removal blocks in the grazer-removal (-fish/ -amphipods) treatment where algal competition would be most intense (Figs. 3 and 7). Moreover, the substantially higher final cover of browns in the fish-dominated treatment compared with the grazer-removal treatment (Figs. 2 and 3) seems most straightforwardly interpreted as resulting from the removal of red and green algae by fish. These patterns are consistent with a role for green algal competitive dominance in depressing brown algal cover.

Thus, our results imply that brown algal dominance requires suppression of amphipod grazing and possibly suppression of algal competitors. In the field these factors generally coincide because the dominant sparid fishes in our system (including both Diplodus holbrooki and Lagodon rhomboides) feed heavily on both am- phipods (Adams 1976b, Nelson 1979b, Stoner 1980a, Darcy $1985 a, b$ ) and red and green algae (Hay 1986, Hay et al. 1987, 1988). Moreover, field observations are consistent with our results in that brown seaweeds dominate the benthos during summer (Hay 1986, Miller and Hay 1996), when fish density is high and amphipod density is low (Holmlund et al. 1990, Duffy and Hay $1991 b$ ). In summary, brown dominance in this system appears to be facilitated by a mechanism akin to the trophic cascade (Carpenter et al. 1985) in which fish predation suppresses density or activity of grazing amphipods, which in turn allows brown seaweeds to flourish (Fig. 12).

This is among the first controlled experimental demonstrations that mesograzers strongly affect benthic community organization, and particularly the abundance of late-successional macroalgae. Although our experiment was not conducted in the field, it overcame many of the limitations that have historically con- 


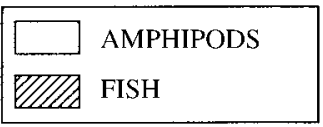

ISOLATED EFFECTS
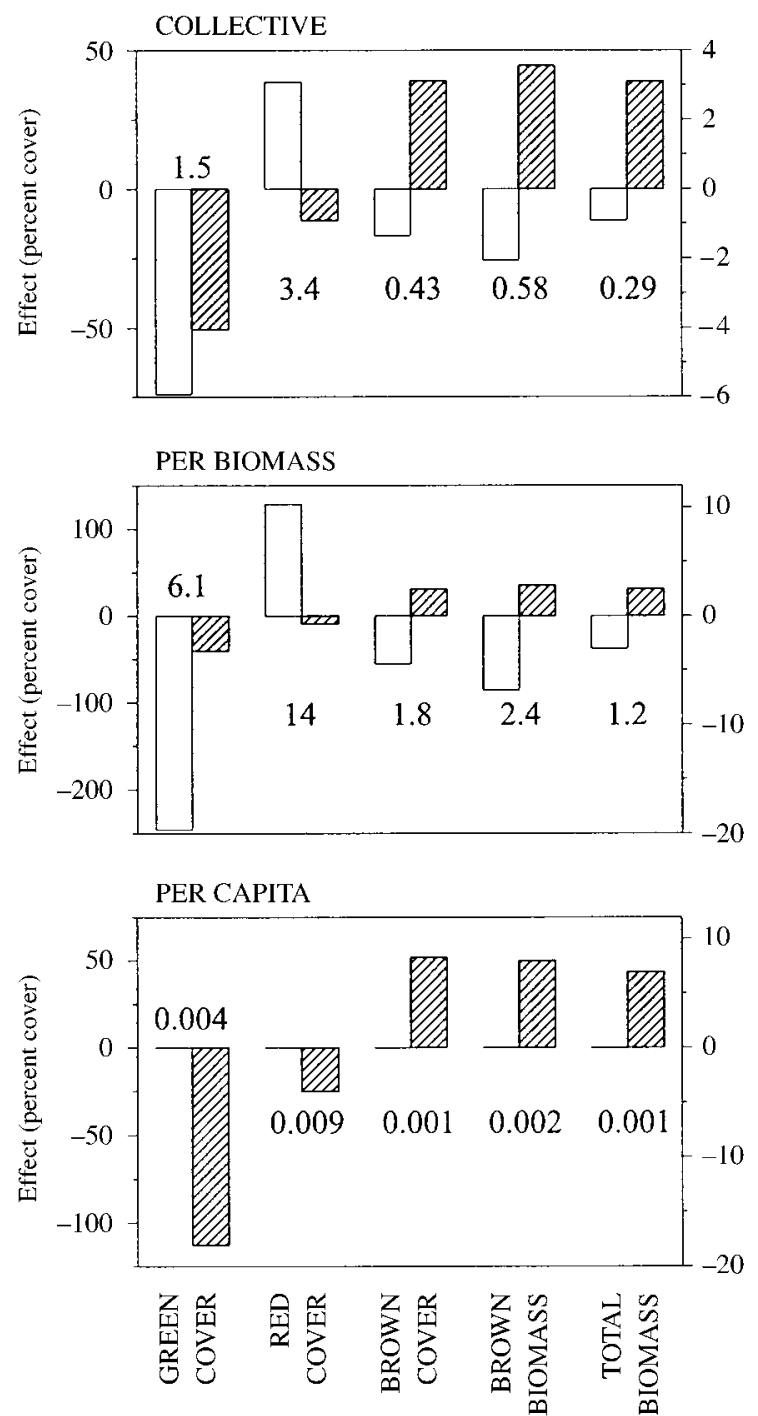

NET EFFECTS
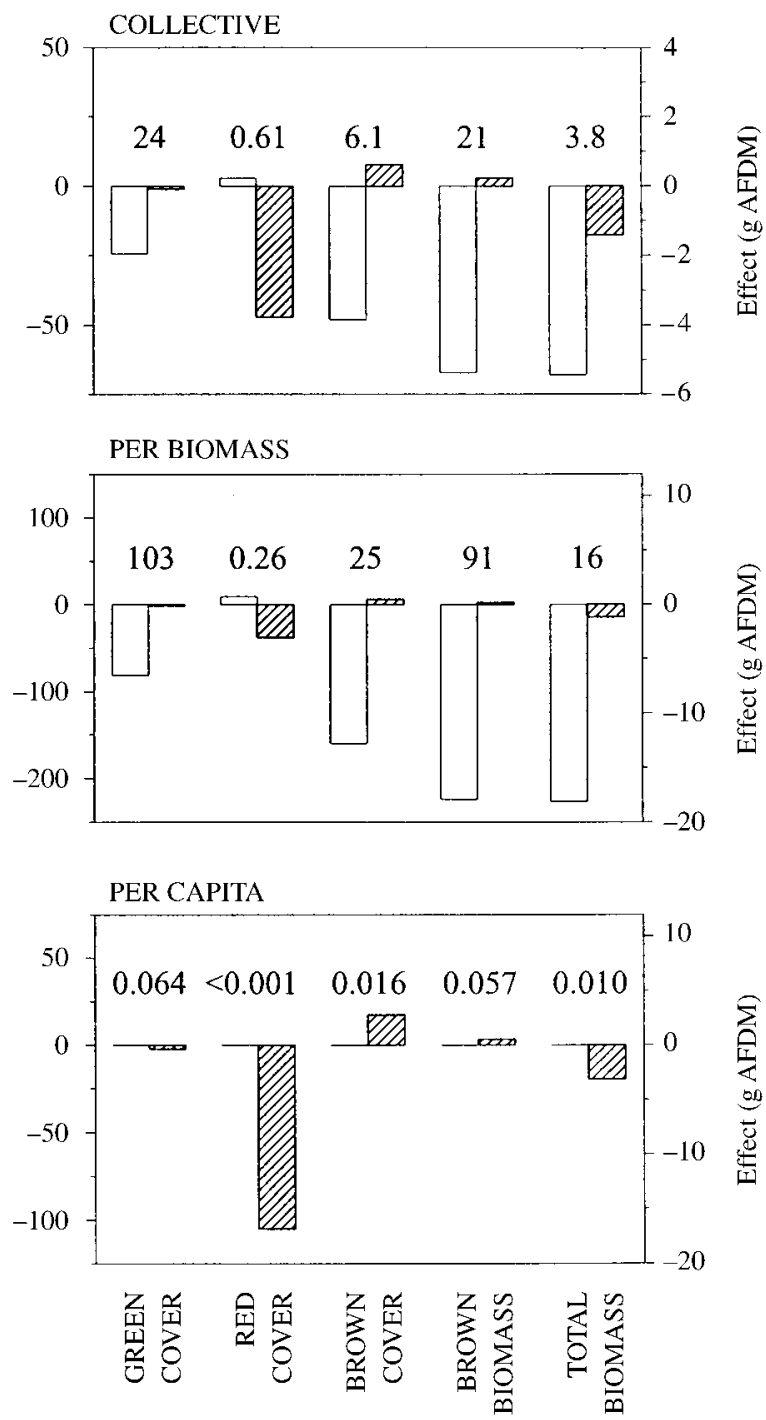

FIG. 11. Comparative impacts (estimated interaction strengths) of fish and grazing amphipods on abundance of major algal groups. The isolated effect of a grazer is the difference in algal abundance between the treatment containing only that grazer (e.g., for amphipods, - fish/+amphipods) and the treatment containing no grazers ( - fish/-amphipods). The net effect is the difference between the treatment containing both grazers (+fish/+amphipods) and the treatment where the target grazer has been deleted (for amphipods, +fish/-amphipods). The collective effect is the raw, arithmetic difference between the two treatments. The per-biomass effect is the collective effect divided by estimated grazer biomass per block, and the per capita effect is the collective effect divided by estimated grazer abundance per block. The number under each pair of bars shows the absolute value of the ratio of effects for amphipods over fish.

strained our understanding of mesograzer community impacts. The experiment was replicated, conducted in large $(\sim 4000 \mathrm{~L})$ tanks with regular wave action, supplied with flowing, unfiltered seawater containing algal and animal propagules, exposed to ambient environmental conditions, extended through most (five months) of the warm growing season, and included most common species of algae, sessile invertebrates, and mesograzers found at local field sites. In general, the algal flora that developed in our tanks (Fig. 2) was similar to that found on local hard substrata in the field (Table 1, Hay 1986, Miller and Hay 1996; M. E. Hay, 

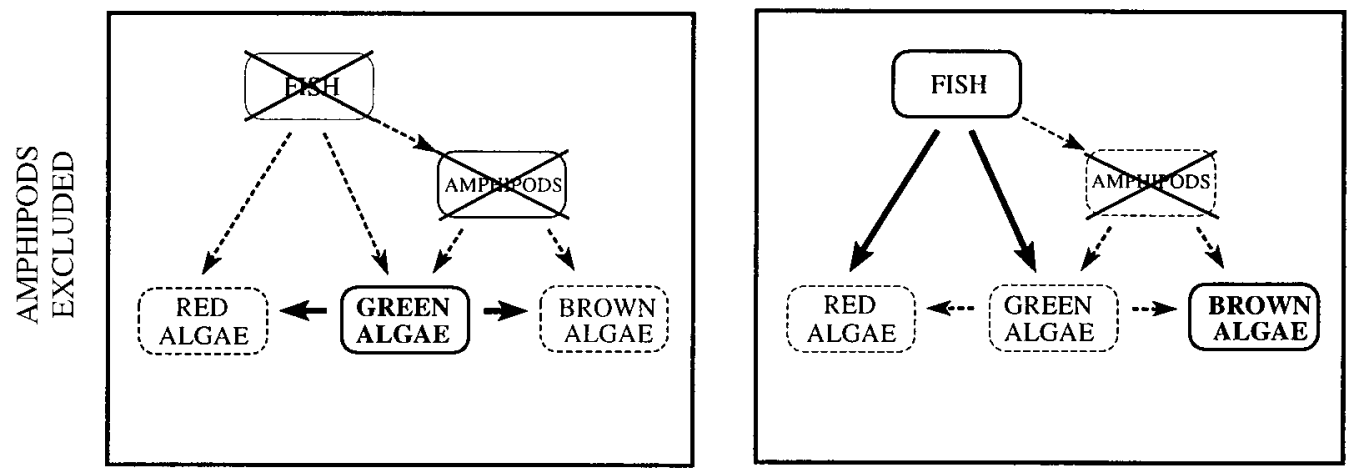

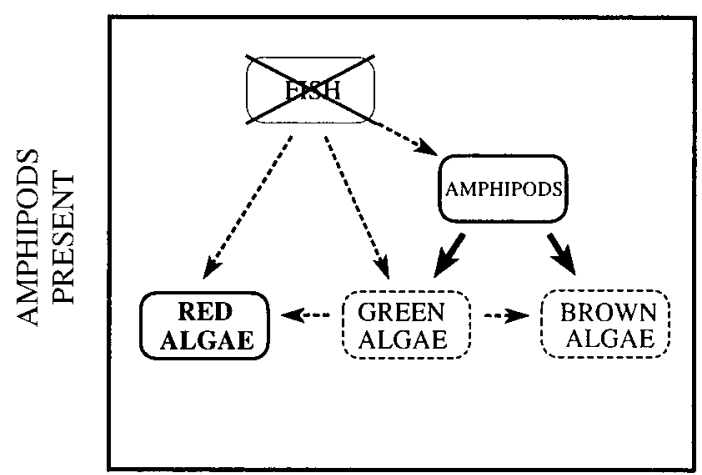

NO FISH

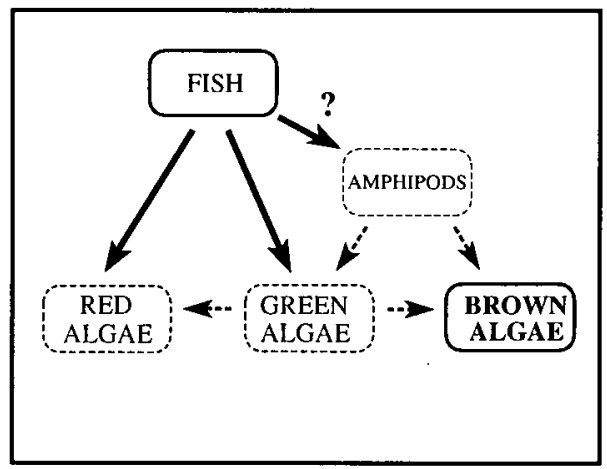

FISH

FIG. 12. Schematic summary of processes organizing the benthic community in each of the four grazer treatments. Solid arrows indicate negative impacts of consumption (downward arrows) or competition (horizontal arrows); dotted lines indicate potential interactions that are inhibited in the treatment. Dominant algal taxa in each treatment are indicated in bold. The question mark in the lower right panel reflects uncertainty about the degree to which predation controls amphipod grazing (see Discussion: A trophic cascade involving mesograzers?).

unpublished data). Epifaunal assemblages in the tanks (Table 6) were diverse and contained most of the species common at local field sites (Duffy 1989, 1990). The most obvious difference between our tanks and field communities was the higher densities of amphipods in the tanks. The principal mesograzer Ampithoe longimana in September averaged 20 individuals/g wet algae in the amphipod-dominated treatment, and 17 individuals/g wet algae in the fish+amphipod treatment. These compare with summer densities of $\leq 5 \mathrm{~A}$. longimana/g wet algae measured on browns in the field (Table 1). The likely explanation for the higher amphipod densities in our tanks is that each experimental compartment occupied only one-fourth of the total tank volume, such that the remainder of the tank effectively served as a refuge from fish predation. Amphipods sustained large populations in these refuge areas (as evidenced by their densities in the adjoining amphipoddominated treatments). These higher local densities could counteract fish depression of amphipod densities within the fish+amphipod treatment by facilitating continuous colonization, especially at night when these fish do not feed but when amphipods remain active. Our tanks also lacked the wrasses, blennies, gobies, and other small carnivorous fishes that may contribute to reduced epifaunal densities in the field.

These considerations suggest that amphipod densities in the + fish/+amphipods treatment were abnormally high, and thus that the strong net effects of amphipods (which use this treatment as a standard, Fig. 11 ) in the experiment are likely inflated compared with their effects in the field. In contrast, the amphipoddominated (-fish/+amphipod) treatment presumably approximates natural amphipod densities in the absence of fish predation. Thus, the strong impacts of amphipods in the absence of fish (isolated effects, Fig. 11) are less likely to be artifactual. We therefore believe that the isolated effects of amphipods (Fig. 11) are a realistic estimate of their potential community impacts where fish predation is negligible, whereas our finding of strong amphipod impacts in the presence of fish is suggestive but needs reexamination under more realistic amphipod densities.

\section{A trophic cascade involving mesograzers?}

In the absence of other grazers, amphipods in our experiment had stronger collective impacts (isolated effects, Fig. 11) on red and green algae than did fish. 
Moreover, on a per-biomass basis, amphipods had stronger impacts than fish on all algal response variables except the net effect on red algae. A potentially general implication of these results is that in the absence of fish predation, amphipod populations can attain densities high enough to cause substantial damage to macroalgae, with pervasive consequences for benthic community structure (Fig. 12). Supporting this possibility, amphipod densities similar to those we observed are not uncommon in nature. Total amphipod densities at local field sites averaged $\sim 130$ individuals/ $\mathrm{g}$ wet algae in spring (Table 1), before fishes begin feeding heavily on benthic crustaceans (Duffy and Hay $1991 b$ ), and seaweed-associated amphipods in systems throughout the world can reach similarly high densities (Wieser 1952, Mukai 1971, Choat and Kingett 1982, D’Antonio 1985, Edgar and Aoki 1993, Lancellotti and Trucco 1993). Although only a subset of amphipod species are herbivorous, our results suggest that such densities can produce significant grazing impacts on community organization. This raises two questions: (1) What factors prevent most grazing amphipod populations in the field from reaching the high densities observed in our tanks? And, (2) how general are such amphipod-mediated impacts on community organization likely to be? We consider the first question here and the second in the next section.

First, despite decades of interest, the regulation of mobile epifaunal population densities remains poorly understood. On the one hand, there is a wealth of circumstantial evidence for a controlling influence of predation, most commonly showing that densities and body sizes of epifauna are negatively correlated with the abundance of predators, mostly fishes (Van Dolah 1978, Nelson 1979b, Edgar 1983a, b, Duffy and Hay $1991 b$ ), and a few experimental studies provide some support for this hypothesis (Kennelly 1983, 1991, Leber 1985). On the other hand, many experimental studies have failed to demonstrate a clear negative impact of fish predation on mobile epifauna in the field (Young and Young 1978, Nelson 1981, Choat and Kingett 1982, Holmlund et al. 1990, Martin-Smith 1993). Often the lack of a predation effect appears due either to rapid movement of epifauna through cage walls, or to the formidable artifacts involved in caging experiments with such small animals. In our experiment, epifaunal taxa differed substantially in their responses to fish. The snail Diastoma, for example, showed no hint of reduction by fish. When considered individually, abundances of crustacean grazer species (Ampithoe longimana, Paracerceis caudata, Dulichiella appendiculata, and Caprella penantis), also were not significantly reduced by fish. When their abundances were pooled, however, fish depressed aggregate density of crustacean grazers $(P=0.046$, split-plot ANOVA) by $45 \%$ relative to the treatment where mesograzers but not fish were present. That the suppression of amphipod densities or activities by fish has cascading impacts on the seaweed assemblage is supported by the $64 \%$ higher cover of browns in the treatment with both fish and amphipods than in the treatment with amphipods alone (Fig. 3), and by the significant fish $\times$ amphipod interaction for loss of brown algal mass in the August grazing assay (Results: Grazer impacts). As discussed above, we suspect that these effects of fish are conservative due to the extensive refuge space available in our tanks that likely reduced the impact of fish on amphipods in these experiments. If fish predation similarly limits populations of mesograzers in the field, their preferred foods (brown algae in this study) could be facilitated by fishes through a trophic cascade mechanism similar to that demonstrated for total algal biomass in freshwaters (Carpenter et al. 1985, Power 1990) and other marine hard-bottoms (Estes and Palmisano 1974, Estes and Duggins 1995, Wootton 1995, Estes et al. 1998).

\section{Is amphipod grazing ecologically significant?}

The second question raised by our results is how frequently amphipod grazing plays a significant role in benthic community organization. Grazing amphipods are ubiquitous in marine benthic communities but they have rarely been satisfactorily manipulated in a community study (see Carpenter 1986 for an exception), in large part because of formidable logistical hurdles. For this reason, among others, their potential role in community organization is largely unknown. Nevertheless, there is some precedent for our results in several previous experimental studies (see Introduction), most notably the pioneering work of Brawley and Adey (1981). Using a coral reef mesocosm, these authors showed that algal assemblage dominance shifted from filamentous species to red macroalgae after amphipods (Ampithoe raimondi) invaded the tank, a result strikingly similar to our findings (Figs. 2 and 3). Other experimental studies, while not targeting mesograzers specifically, demonstrated changes in algal assemblage structure within exclusion cages that coincided with increased density of mobile epifauna (Kennelly 1983, 1991, Zeller 1988). Although experimental manipulations of mesograzers are rare, several anecdotal observations similarly implicate certain amphipods as important grazers in other marine benthic communities. Interestingly, the most striking cases of mesograzer impacts on benthic community organization disproportionately involve amphipods in the family Ampithoidae, as did our study and that of Brawley and Adey (1981). Ampithoids are characteristics members of benthic macrophyte beds throughout the world, including southern-hemisphere (Kreibolm de Paternoster and Escofet 1976, Tararam and Wakabara 1981, Edgar $1983 a, d)$ and northern-hemisphere kelp and other brown algal beds (Mukai 1971, Gunnill 1982, Tegner and Dayton 1987, Duffy 1990, Chess 1993), seagrass beds (Nagle 1968, Marsh 1973, Nelson 1979a, Stoner 1980b, Virnstein and Howard 1987), and tropical algal beds (Lewis and Kensley 1982, Hay et al. 1990, 1994). 
Although the feeding habits of most of these amphipods are poorly known, those that have been studied generally show mild to strong preference for, or at least association with, brown algae (Griffiths 1979, Conlan and Bousfield 1982, Lewis and Kensley 1982, Hay et al. 1987, 1990, Duffy 1990, Poore and Steinberg 1999, Cruz-Rivera and Hay 2000). There are several other reports of important impacts on benthic communities by ampithoids. Chess (1993) observed destruction of kelps at several sites along the Pacific coast of North America when the stipe-boring ampithoid Peramphithoe stypotrupetes was abundant. Perhaps most intriguing are the reports of massive kelp and macroalgal deforestation in California following the El Niños of the 1960s and early 1980s (Tegner and Dayton 1987). After cool waters returned in the wake of El Niño, kelp populations recovered and grew vigorously. Recovery of kelp-associated fish populations lagged behind, however, and the newly recovered kelp beds suffered another catastrophic decline coincident with a population explosion of the kelp curler amphipod Peramphithoe humeralis, which was hypothesized to have escaped predatory control (Tegner and Dayton 1987). This chain of events bears striking similarities to what we observed in our mesocosm experiment.

\section{Opening the black box of mesograzers}

Our experiment illustrates dramatically the diversity in functional roles that can occur among superficially similar taxa at the same trophic level, even within putative functional groups (see also Paine 1992, Wootton 1997). While it is not surprising that herbivorous fishes and mesograzers should have divergent impacts on the plant assemblage, the differences among species of mesograzers are more intriguing. Several previous studies have shown that co-occurring mesograzer species can have quite different feeding preferences (Zimmerman et al. 1979, Duffy 1990, Duffy and Hay 1994, Cruz-Rivera and Hay 2000) and our laboratory assays corroborate these previous studies (Fig. 9). This study confirms that these differences have important consequences for community organization. Specifically, the red seaweed assemblage that developed in the amphipod-dominated treatment differed dramatically from those in all other treatments, despite the fact that total epifaunal density and even total mesograzer density showed no significant differences among treatments. Explaining the facilitation of red algae by mesograzers thus requires finer taxonomic resolution. Several lines of evidence suggest that this effect was attributable almost entirely to the single amphipod species Ampithoe longimana. First, insecticide treatment significantly suppressed only amphipods, of which A. longimana was the most abundant, whereas numbers of snails and isopods were not suppressed by either insecticide or fish. Second, A. longimana was the only amphipod in our tanks that fed readily on brown macroalgae in laboratory assays. Finally, Sargassum fronds sampled from mesograzer treatments were ex- tensively damaged by grazing scars of the type produced by A. longimana, resulting in significantly reduced individual frond area compared with other treatments.

Our results thus show not only that mesograzers can have significant impacts on benthic community structure, but also imply that these impacts can be highly species specific. The common practice of tabulating epifaunal species by higher taxonomic categories, or even by functional groups (with function usually being assumed rather than known), would have obscured the important role of grazing amphipods in this system. Clearly the simple size-based classification of grazers common in food web studies and ecosystem models is too coarse grained to predict plant assemblage composition in this system. In fact, the specificity of grazer impacts goes beyond the nuances of species composition to the total standing stock of primary producers, arguably the single most important term in ecosystem models. Specifically, in the presence of fish, removal of grazing amphipods with insecticide resulted in a $>300 \%$ increase in total plant biomass (Fig. 5), despite the similarity in total mesograzer abundances in the two treatments (Fig. 7). Similar points about the community- or ecosystem-level consequences of speciesspecific ecology have been made for terrestrial (Polis 1991, Polis and Strong 1996), benthic marine (Paine 1969, 1980, 1992), and pelagic marine systems (Lehman 1988).

One of the more surprising results of our study was the relative strength of amphipod impacts on the algal assemblage in comparison with those of fish (Fig. 11). These comparisons rely on several assumptions (Table 2). First, our estimates of amphipod biomass are indirect; they assume that abundances were similar in September (when mesograzer numbers were measured) and at other times (when treatment effects were measured), and similar on brown macroalgae vs. benthos as a whole. Although our calculations of effect strength involved several such steps, we believe that the final result is conservative with respect to conclusions about amphipod importance, for two reasons. First, the measured abundance of mesograzers, and particularly Ampithoe longimana, was likely higher on the brown algae we deployed to collect them than on benthic organisms in aggregate, both because these browns generally support higher densities of $A$. longimana than do other algae, and because $A$. longimana abundance in the field peaks in late summer when we collected our samples for abundance (Duffy and Hay 1991b, 1994). This will tend to overestimate abundance of amphipods in the tanks, and thus underestimate their per-biomass effects. Second, we calculated effects for amphipods as a group since our experimental design removed all amphipod species collectively, rather than as single species. Thus, the most conservative interpretation of our results would attribute community changes in the insecticide treatments to the amphipod guild collectively; this is what we have done in Fig. 11. Yet our laboratory feed- 
ing assays, and the relative abundance of mesograzer species in the tanks, provide evidence that these community changes are attributable primarily, if not solely, to the single amphipod species Ampithoe longimana. This amphipod had the highest overall feeding rates of any mesograzer examined, and was the only one that fed appreciably on brown macroalgae. Again, this makes our calculation of effect strength for grazing amphipods conservative because the per-biomass effect is calculated from biomass of all grazing amphipods rather than the fraction of that biomass made up by $A$. longimana, which likely produces the strong effects. Calculation of effects for A. longimana alone results in slightly higher values. Thus, while the unusually high densities of amphipods in the normal (+fish/+amphipod) treatment may inflate our estimates of net effects (Fig. 11), our experiment shows clearly that grazing amphipods can have dramatic impacts on benthic macroalgal assemblages, a role which has been virtually unrecognized compared with the widely appreciated roles of fishes and large invertebrates such as sea urchins.

We suggest that the community impacts of these abundant but inconspicuous animals deserve more attention. In the last two decades it has become clear that in many oceanic systems, the majority of primary production and the majority of grazing activity are mediated by very small algae, protists, and bacteria that had passed through the plankton nets traditionally used by oceanographers (Pomeroy 1974, Azam et al. 1983, Li et al. 1983). In soft-bottom marine communities, a growing body of evidence indicates that small predatory invertebrates, including polychaetes, amphipods, and meiofaunal turbellarians, have significant impacts on both the adults and settling larvae of benthic macrofauna, which demonstrably affect community structure in some cases and are suspected of doing so in others (Watzin, 1983, 1986, Commito and Ambrose 1985, Osman et al. 1992, Ólaffson et al. 1994, Osman and Whitlatch 1995). Similarly, grazing amphipods are common and often abundant on the rocky marine bottoms that have stimulated so much groundbreaking research in community ecology. Our results suggest that increased attention to these animals will yield important insights into how such systems work.

\section{ACKNOWLEDGMENTS}

We thank Buffy Turner, Quaker Kappel, and Bob Tempe for help with the experiments, Greg Skilleter for statistical consultation, and Eric Berlow, Jim Estes, Bruce Menge, Bob Paine, and Richard Taylor for helpful comments on previous versions of the manuscript. This research was supported by NSF grants OCE 89-11872 and 95-29784 to M. E. Hay and OCE 95-21184 to J. E. Duffy.

\section{Literature Cited}

Adams, S. M. 1976a. The ecology of eelgrass (Zostera marina L.) fish communities. I. Structural analysis. Journal of Experimental Marine Biology and Ecology 22:269-291.

Adams, S. M. 1976b. Feeding ecology of eelgrass fish com- munities. Transactions of the American Fisheries Society 105:514-519.

Azam, F., T. Fenchel, J. G. Field, J. S. Gray, L. A. MeyerReil, and T. F. Thingstad. 1983. The ecological role of water-column microbes in the sea. Marine Ecology Progress Series 10:257-263.

Berlow, E. L., S. A. Navarrete, C. J. Briggs, M. E. Power, and B. A. Menge. 1999. Quantifying variation in the strengths of species interactions. Ecology 80:2206-2224.

Brawley, S. H. 1992. Mesoherbivores. Pages 235-263 in D. M. John, S. J. Hawkins, and J. H. Price, editors. Plantanimal interactions in the marine benthos. Systematics Association Special Volume 46. Clarendon Press, Oxford, UK.

Brawley, S. H., and W. H. Adey. 1981. The effect of micrograzers on algal community structure in a coral reef microcosm. Marine Biology 61:167-177.

Buchanan, D. V., D. L. Bottom, and D. A. Armstrong. 1985. The controversial use of the insecticide Sevin in Pacific Northwest estuaries: its effects on dungeness crab, Pacific oyster, and other species. Proceedings of the Symposium on Dungeness Crab Biology and Management. Alaska Sea Grant Report 85-3:401-417.

Carpenter, R. C. 1986. Partitioning herbivory and its effects on coral reef algal communities. Ecological Monographs 56:345-363.

Carpenter, S. R., J. F. Kitchell, and J. R. Hodgson. 1985. Cascading trophic interactions and lake productivity. BioScience 35:634-639.

Casida, J. E. 1963. Modes of action of carbamates. Annual Review of Entomology 8:39-58.

Chess, J. R. 1993. Effects of the stipe-boring amphipod Peramphithoe stypotrupetes (Corophioidea: Ampithoidae) and grazing gastropods on the kelp Laminaria setchelli. Journal of Crustacean Biology 13:638-646.

Choat, J. H., and P. D. Kingett. 1982. The influence of fish predation on the abundance cycles of an algal turf invertebrate fauna. Oecologia 54:88-95.

Colman, J. 1940. On the faunas inhabiting intertidal seaweeds. Journal of the Marine Biological Association of the United Kingdom 24:129-183.

Commito, J. A., and W. G. Ambrose. 1985. Multiple trophic levels in soft-bottom communities. Marine Ecology Progress Series 26:289-293.

Conlan, K. E., and E. L. Bousfield. 1982. Studies on amphipod crustaceans of the northeast Pacific region. I.2. Family Ampithoidae. National Museums of Canada Publications in Biological Oceanography 10:41-75.

Connell, J. H. 1972. Community interactions on marine rocky intertidal shores. Annual Review of Ecology and Systematics 3:169-192.

Cronin, G., and M. E. Hay. 1996. Induction of seaweed chemical defenses by amphipod grazing. Ecology 77:22872301.

Cruz-Rivera, E., and M. E. Hay. 2000. Can quantity replace quality? Food choice, compensatory feeding, and fitness of marine mesograzers. Ecology 81:201-219.

D'Antonio, C. 1985. Epiphytes on the rocky intertidal alga Rhodomela larix (Turner) C. Agardh: negative effects on the host and food for herbivores? Journal of Experimental Marine Biology and Ecology 86:197-218.

Darcy, G. H. 1985a. Synopsis of biological data on the pinfish, Lagodon rhomboides (Pisces:Sparidae). National Oceanic and Atmospheric Administration Technical Report NMFS 23. U.S. Department of Commerce, Washington, D.C., USA.

Darcy, G. H. 1985b. Synopsis of biological data on the spottail pinfish, Diplodus holbrooki (Pisces:Sparidae). National Oceanic and Atmospheric Administration Technical Report NMFS 19. U.S. Department of Commerce, Washington, D.C., USA. 
Dayton, P. K. 1971. Competition, disturbance, and community organization: the provision and subsequent utilization of space in a rocky intertidal community. Ecological Monographs 41:351-389.

Dayton, P. K. 1975. Experimental evaluation of ecological dominance in a rocky intertidal algal community. Ecological Monographs 45:137-159.

Dayton, P. K. 1985. Ecology of kelp communities. Annual Review of Ecology and Systematics 16:215-245.

Dean, R. L., and J. H. Connell. 1987. Marine invertebrates in an algal succession. I. Variations in abundance and diversity with succession. Journal of Experimental Marine Biology and Ecology 109:195-215.

Duffy, J. E. 1989. Ecology and evolution of herbivory by marine amphipods. Dissertation. University of North Carolina at Chapel Hill, North Carolina, USA.

Duffy, J. E. 1990. Amphipods on seaweeds: partners or pests? Oecologia 83:267-276.

Duffy, J. E., and M. E. Hay. 1991a. Amphipods are not all created equal: a reply to Bell. Ecology 72:354-358.

Duffy, J. E., and M. E. Hay. 1991b. Food and shelter as determinants of food choice by an herbivorous marine amphipod. Ecology 72:1286-1298.

Duffy, J. E., and M. E. Hay. 1994. Herbivore resistance to seaweed chemical defense: the roles of mobility and predation risk. Ecology 75:1304-1319.

Edgar, G. J. 1983a. The ecology of southeast Tasmanian phytal animal communities. I. Spatial organization on a local scale. Journal of Experimental Marine Biology and Ecology 70:129-157.

Edgar, G. J. 1983b. The ecology of southeast Tasmanian phytal animal communities. II. Seasonal change in plant and animal populations. Journal of Experimental Marine Biology and Ecology 70:159-179.

Edgar, G. J. 1983c. The ecology of southeast Tasmanian phytal animal communities. III. Patterns of species diversity. Journal of Experimental Marine Biology and Ecology 70: 181-203.

Edgar, G. J. 1983d. The ecology of southeast Tasmanian phytal animal communities. IV. Factors affecting the distribution of ampithoid amphipods among algae. Journal of Experimental Marine Biology and Ecology 70:205-225.

Edgar, G. J. 1990. The influence of plant structure on the species richness, biomass and secondary production of macrofaunal assemblages associated with Western Australian seagrass beds. Journal of Experimental Marine Biology and Ecology 137:215-240.

Edgar, G. J. 1993. Measurement of the carrying capacity of benthic habitats using a metabolic-rate based index. Oecologia 95:115-121.

Edgar, G. J., and M. Aoki. 1993. Resource limitation and fish predation: their importance to mobile epifauna associated with Japanese Sargassum. Oecologia 95:122-133.

Edgar, G. J., and C. Shaw. 1995. The production and trophic ecology of shallow-water fish assemblages in southern Australia. III. General relationships between sediments, seagrasses, invertebrates and fishes. Journal of Experimental Marine Biology and Ecology 194:107-131.

Estes, J. A., and D. O. Duggins. 1995. Sea otters and kelp forests in Alaska: generality and variation in a community ecological paradigm. Ecological Monographs 65:75-100.

Estes, J. A., and J. F. Palmisano. 1974. Sea otters: their role in structuring nearshore communities. Science 185:10581060.

Estes, J. A., M. T. Tinker, T. M. Williams, and D. F. Doak 1998. Killer whale predation on sea otters linking oceanic and nearshore systems. Science 282:473-476.

Fredette, T. J., and R. J. Diaz. 1986. Secondary production of Gammarus mucronatus Say (Amphipoda: Gammaridae) in warm temperate estuarine habitats, York River, Virginia. Journal of Crustacean Biology 6:729-741.

Fredette, T. J., R. J. Diaz, J. van Montfrans, and R. J. Orth. 1990. Secondary production within a seagrass bed (Zostera marina and Ruppia maritima) in lower Chesapeake Bay. Estuaries 13:431-440.

Griffiths, C. L. 1979. A redescription of the kelp curler Ampithoe humeralis (Crustacea, Amphipoda) from South Africa and its relationship to Macropisthopous. Annals of the South African Museum 79:131-138.

Gunnill, F. C. 1982. Macroalgae as habitat patch islands for Scutellidium lamellipes (Copepoda: Harpacticoida) and Ampithoe tea (Amphipoda: Gammaridea). Marine Biology 69:103-116.

Haahtela, I. 1984. A hypothesis of the decline of the bladder wrack (Fucus vesiculosus L.) in SW Finland in 1975-1981. Limnologica 15:345-350.

Hairston, N. G. 1989. Ecological experiments: purpose, design, and execution. Cambridge University Press, Cambridge, UK.

Hay, M. E. 1986. Associational plant defenses and the maintenance of species diversity: turning competitors into accomplices. American Naturalist 128:617-641.

Hay, M. E. 1991. Fish-seaweed interactions on coral reefs: effects of herbivorous fishes and adaptations of their prey. Pages 96-119 in P. F. Sale, editor. The ecology of fishes on coral reefs. Academic Press, New York, New York, USA.

Hay, M. E. 1997. The ecology and evolution of seaweedherbivore interactions on coral reefs. Coral Reefs 16:S67S76.

Hay, M. E., J. E. Duffy, and W. Fenical. 1990. Host-plant specialization decreases predation on a marine amphipod: an herbivore in plant's clothing. Ecology 71:733-743.

Hay, M. E., J. E. Duffy, C. A. Pfister, and W. Fenical. 1987. Chemical defense against different marine herbivores: are amphipods insect equivalents? Ecology 68:1567-1580.

Hay, M. E., Q. E. Kappel, and W. Fenical. 1994. Synergisms in plant defenses against herbivores: interactions of chemistry, calcification, and plant quality. Ecology 75:17141726.

Hay, M. E., P. E. Renaud, and W. Fenical. 1988. Large mobile versus small sedentary herbivores and their resistance to seaweed chemical defense. Oecologia 75:246-252.

Hay, M. E., and J. P. Sutherland. 1988. The ecology of rubble structures of the South Atlantic Bight: a community profile. Biological Report 85(7.20). United States Fish and Wildlife Service, Department of the Interior, Washington, D.C., USA.

Holmlund, M. B., C. H. Peterson, and M. E. Hay. 1990. Does algal morphology affect amphipod susceptibility to fish predation? Journal of Experimental Marine Biology and Ecology 139:65-83.

Hughes, T. P. 1994. Catastrophes, phase shifts, and largescale degradation of a coral reef. Science 256:1547-1551.

Jernakoff, P., A. Brearley, and J. Nielsen. 1996. Factors affecting grazer-epiphyte interactions in temperate seagrass meadows. Oceanography and Marine Biology: an Annual Review 34:109-162.

John, D. M., S. J. Hawkins, and J. H. Price, editors. 1992. Plant-animal interactions in the marine benthos. Clarendon, Oxford, UK.

Kangas, P., H. Autio, G. Hällfors, H. Luther, Å. Niemi, and H. Salemaa. 1982. A general model of the decline of Fucus vesiculosus at Tvärminne, south coast of Finland in 19771981. Acta Botanica Fennica 118:1-27.

Kennelly, S. J. 1983. An experimental approach to the study of factors affecting algal colonization in a sublittoral kelp forest. Journal of Experimental Marine Biology and Ecology 68:257-276. 
Kennelly, S. J. 1991. Caging experiments to examine the effects of fishes on understorey species in a sublittoral kelp community. Journal of Experimental Marine Biology and Ecology 147:207-230.

Kikuchi, T. 1974. Japanese contributions on consumer ecology in eelgrass (Zostera marina L.) beds, with special reference to trophic relationships and resources in inshore fisheries. Aquaculture 4:145-160.

Kitting, C. L., B. Fry, and M. D. Morgan. 1984. Detection of inconspicuous epiphytic algae supporting food webs in seagrass meadows. Oecologia 62:145-149.

Kreibolm de Paternoster, I., and A. Escofet. 1976. La fauna de anfipodos asociado a los bosques de Macrocystis pyrifera en el chabut: Ampithoe femorata (Krøyer) (Ampithoidae) and Bircenna fulva Chilton (Eophliantidae). Physis A 35:77-91.

Lancellotti, D. A., and R. G. Trucco. 1993. Distribution patterns and coexistence of six species of the amphipod genus Hyale. Marine Ecology Progress Series 93:131-141.

Lande, R. 1996. Statistics and partitioning of species diversity, and similarity among multiple communities. Oikos 76: 5-13.

Laska, M. S., and J. T. Wootton. 1998. Theoretical concepts and empirical approaches to measuring interaction strength. Ecology 79:461-476.

Leber, K. L. 1985. The influence of predatory decapods, refuge, and microhabitat selection on seagrass communities. Ecology 66:1951-1964.

Lehman, J. T. 1988. Ecological principles affecting community structure and secondary production by zooplankton in marine and freshwater environments. Limnology and Oceanography 33:931-945.

Lessios, H. A. 1988. Mass mortality of Diadema antillarum in the Caribbean: what have we learned? Annual Review of Ecology and Systematics 19:371-393.

Lewis, S. M. 1986. The role of herbivorous fishes in the organization of a Caribbean reef community. Ecological Monographs 56:183-200.

Lewis, S. M., and B. Kensley. 1982. Notes on the ecology and behaviour of Pseudamphithoides incurvaria (Just) (Crustacea, Amphipoda, Ampithoidae). Journal of Natural History 16:267-274.

Li, W. K. W., D. V. Subba Rao, W. G. Harrison, J. C. Smith, J. J. Cullen, B. Irwin, and T. Platt. 1983. Autotrophic picoplankton in the tropical ocean. Science 219:292-295.

Lubchenco, J. 1978. Plant species diversity in a marine intertidal community: importance of herbivore food preference and algal competitive abilities. American Naturalist 112:23-29.

Lubchenco, J., and B. A. Menge. 1978. Community development and persistence in a low rocky intertidal zone. Ecological Monographs 48:67-94.

Marsh, G. A. 1973. The Zostera epifaunal community in the York River, Virginia. Chesapeake Science 14:87-97.

Martin-Smith, K. M. 1993. Abundance of mobile epifauna: the role of habitat complexity and predation by fishes. Journal of Experimental Marine Biology and Ecology 174:243260.

Matsumura, F. 1985. Toxicology of insecticides. Plenum, New York, New York, USA.

Menge, B. A. 1995. Indirect effects in marine rocky intertidal interaction webs: patterns and importance. Ecological Monographs 65:21-74.

Menge, B. A., and J. Lubchenco. 1981. Community organization in temperate and tropical rocky intertidal habitats prey refuges in relation to consumer pressure gradients. Ecological Monographs 51:429-450.

Miller, M. W., and M. E. Hay. 1996. Coral-seaweed-grazernutrient interactions on temperate reefs. Ecological Monographs 66:323-344.
Morrison, D. 1988. Comparing fish and urchin grazing in shallow and deeper coral reef algal communities. Ecology 69:1367-1382.

Mukai, H. 1971. The phytal animals on the thalli of Sargassum serratifolium in the Sargassum region, with reference to their seasonal fluctuations. Marine Biology 8:170182.

Nagle, J. S. 1968. Distribution of the epibiota of macroepibenthic plants. Contributions in Marine Science, University of Texas 13:105-144.

Neckles, H. A., R. L. Wetzel, and R. J. Orth. 1993. Relative effects of nutrient enrichment and grazing on epiphytemacrophyte (Zostera marina L.) dynamics. Oecologia 93 : 285-295.

Nelson, W. G. 1979a. An analysis of structural pattern in an eelgrass (Zostera marina L.) amphipod community. Journal of Experimental Marine Biology and Ecology 39:231-264.

Nelson, W. G. 1979b. Experimental studies of selective predation on amphipods: consequences for amphipod distribution and abundance. Journal of Experimental Marine Biology and Ecology 38:225-245.

Nelson, W. G. 1981. Experimental studies of decapod and fish predation on seagrass macrobenthos. Marine Ecology Progress Series 5:141-149.

Ogden, J. C., R. A. Brown, and N. Salesky. 1973. Grazing by the echinoid Diadema antillarum: formation of halos around West Indian patch reefs. Science 182:715-717.

Ólaffsson, E. B., C. H. Peterson, and W. G. Ambrose, Jr. 1994. Does recruitment limitation structure populations and communities of macro-invertebrates in marine soft sediments: the relative significance of pre- and post-settlement processes. Oceanography and Marine Biology: an Annual Review 32:65-109.

Orth, R. J., and J. van Montfrans. 1984. Epiphyte-seagrass relationships with an emphasis on the role of micrograzing: a review. Aquatic Botany 18:43-69.

Osenberg, C. W., and G. G. Mittelbach. 1995. The relative importance of resource limitation and predator limitation in food chains. Pages 134-149 in G. Polis and K. Winemiller, editors. Food webs: integration of patterns and dynamics. Chapman and Hall, New York, New York, USA.

Osman, R. W., and R. B. Whitlatch. 1995. Predation on early ontogenetic life stages and its effect on recruitment into a marine epifaunal community. Marine Ecology Progress Series 117:111-126.

Osman, R. W., R. B. Whitlatch, and R. J. Malatesta. 1992. Potential role of micro-predators in determining recruitment into a marine community. Marine Ecology Progress Series 83:35-43.

Paine, R. T. 1969. A note on trophic complexity and community stability. American Naturalist 103:91-93.

Paine, R. T. 1980. Food webs: linkage, interaction strength and community infrastructure. Journal of Animal Ecology 49:667-685.

Paine, R. T. 1992. Food-web analysis through field measurements of per capita interaction strength. Nature 355: 73-75.

Paine, R. T., and R. L. Vadas. 1969. The effects of grazing by sea urchins, Strongylocentrotus spp., on benthic algal populations. Limnology and Oceanography 14:710-719.

Polis, G. A. 1991. Complex trophic interactions in deserts: an empirical critique of food web theory. American Naturalist 138:123-155.

Polis, G. A., and D. R. Strong. 1991. Food web complexity and community dynamics. American Naturalist 147:813846.

Pomeroy, L. R. 1974. The ocean's food web, a changing paradigm. BioScience 24:499-504.

Poore, A. G. B., and P. D. Steinberg. 1999. Preference-performance relationships and effects of host plant choice in 
an herbivorous marine amphipod. Ecological Monographs 69:443-464.

Potvin, C. 1993. ANOVA: experiments in controlled environments. Pages 46-68 in S. M. Scheiner and J. Gurevitch, editors. Design and analysis of ecological experiments Chapman and Hall, New York, New York, USA.

Power, M. E. 1990. Effects of fish in river food webs. Science 250:411-415.

Power, M. E., D. Tilman, J. A. Estes, B. A. Menge, W. J. Bond, L. S. Mills, G. Daily, J. C. Castilla, J. Lubchenco, and R. T. Paine. 1996. Challenges in the quest for keystones. BioScience 46:609-620.

Randall, J. E. 1961. Overgrazing of algae by herbivorous marine fishes. Ecology 42:812.

Rice, W. R. 1989. Analyzing tables of statistical tests. Evolution 43:223-225.

Ruppert, E. E., and R. Fox. 1988. Seashore animals of the Southeast. University of South Carolina Press, Columbia, South Carolina, USA

SAS. 1985. SAS user's guide: statistics. Version 5 edition. SAS Institute, Cary, North Carolina, USA.

Schiel, D. R., and M. S. Foster. 1986. The structure of subtidal algal stands in temperate waters. Oceanography and Marine Biology: Annual Review 24:265-307.

Schneider, C. W., and R. B. Searles. 1991. Seaweeds of the southeastern United States. Duke University Press, Durham, North Carolina, USA.

Stoner, A. W. 1980a. Feeding ecology of Lagodon rhomboides (Pisces: Sparidae): variation and functional response. Fishery Bulletin 78:337-352.

Stoner, A. W. $1980 b$. The role of seagrass biomass in the organization of benthic macrofaunal assemblages. Bulletin of Marine Science 30:537-551.

Tararam, A. S., and Y. Wakabara. 1981. The mobile faunaespecially Gammaridea-of Sargassum cymosum. Marine Ecology Progress Series 5:157-163.

Tegner, M. J., and P. K. Dayton. 1987. El Nino effects on southern California kelp forest communities. Advances in Ecological Research 17:243-279.
Van Dolah, R. F. 1978. Factors regulating the distribution and population dynamics of the amphipod Gammarus palustris in an intertidal salt marsh community. Ecological Monographs 48:191-217.

van Montfrans, J., R. L. Wetzel, and R. J. Orth. 1984. Epiphyte-grazer relationships in seagrass meadows: consequences for seagrass growth and production. Estuaries 7: 289-309.

Virnstein, R. W., and R. K. Howard. 1987. Motile epifauna of marine macrophytes in the Indian River Lagoon, Florida. I. Comparisons among three species of seagrasses from adjacent beds. Bulletin of Marine Science 41:1-12.

Watzin, M. C. 1983. The effects of meiofauna on settling macrofauna: meiofauna may structure macrofaunal communities. Oecologia 59:163-166.

Watzin, M. C. 1986. Larval settlement into marine soft-sediment systems: interactions with the meiofauna. Journal of Experimental Marine Biology and Ecology 98:65-113.

Wieser, W. 1952. Investigations on the microfauna inhabiting seaweeds on rocky coasts. IV. Studies on the vertical distribution of the fauna inhabiting seaweeds below the Plymouth Laboratory. Journal of the Marine Biological Association of the United Kingdom 31:145-174.

Wootton, J. T. 1995. Effects of birds on sea urchins and algae: a lower-intertidal trophic cascade. Ecoscience 2:321-328.

Wootton, J. T. 1997. Estimates and tests of per capita interactions strength: diet, abundance, and impact of intertidally foraging birds. Ecological Monographs 67:45-64.

Young, D. K., and M. W. Young. 1978. Regulation of species densities of seagrass-associated macrobenthos: a field experimental study of predation. Journal of Marine Research 36:569-593.

Zeller, D. C. 1988. Short-term effects of territoriality of a tropical damselfish and exclusion of large fishes on invertebrates in algal turfs. Marine Ecology Progress Series 44: 85-93.

Zimmerman, R., R. Gibson, and J. Harrington. 1979. Herbivory and detritivory among gammaridean amphipods from a Florida seagrass community. Marine Biology 54: $41-47$. 